\begin{tabular}{llll}
\hline 技 & 術 & 資 & 料 \\
\hline
\end{tabular}

\title{
低炭素鋼板の集合組織と深絞り性*
}

\author{
長 島 晋 一**. 武 智弘**
}

\author{
Relationship between Deep Drawability and
}

Textures in Low Carbon Steel Sheets

\section{1. 緒亩}

最近薄鋼板の集合組織についての関心が急速に高まり この分野の研究結果が数多く発表されるようになつた. これはプレス成形して用いられる薄鋼板の品質が集合組 織によつて大きな影響を受け，そのコントロールによつ て品質を著しく向上させうることが明らかにされたの で，大きな需要を持つこの種薄鎆板の製造にたずさわる 技術者が集合組織に関する研究を重視するようになつた ためと考えられる.

集合組織の形成機構に関する基礎的研究は, 電磁気材 料用鉄板 - 珪素鋼板における磁気的性質の改良を目的之 して，古くから多数の研究者によつて進められてきたの で，加工性向上に関する集合組織の研究もこれらの過去 の成果に支えられて飛躍的発展を逐げた.

薄鋼板の加工性に関する集合組織の研究は大別して 3 つの段階に分けられる。第 1 は薄銀板の成形性に影響を 及ほす因子の1つとして塑性異方性が注目されはじめた 段階, 第 2 は特定の優先方位が成形性に好ましい奻果を 持つことが判明し, 定量的追求がはじめられた段階, 第 3 は好ましい方位を持つ集合組織をコントロールして薄 銅板の品質向上を計りつつある現在の段階である. 今後 はさらに特殊元素を利用した集合組䋨のコントロール， あるいは新しいプロセスによる集合組織のコントロール などの研究, 体心立方晶以外の結晶構造を持つ非鉄金属 材料の成形性その他の特性と集合組織との関連の解明な と一層厇い分野の研究に発展していくであろうと考えら れる.

すてに本誌にも薄鋼板の集合組織に関する研究がいく つか報告され，集合組織形成機棈に関する解説も技術資 料として揭载されているいが，現時点で成形性に関する 今日までの研究の発展の過程をふり返つて見ることは意

\footnotetext{
* 依頼技術资料 昭和 43 年 4 月20日受付
}

** 八幡彆鉄(株)技術研究所工博
Shin'ichi Nagashima and Hiroshi TAkechl

義あることであろうと考え，特に深絞り性と集合組織と の関係に中心をおき主要な研究結果ををとめてみた.

\section{2. 深絞り性とランクフォード值}

\section{$2 \cdot 1$ ランクフォード值（r-value）とプレス成形性}

薄鋼板のプレス成形においては等方的材料が望ましい というのが一般的通念であつたが, LANKFORD, SNYDRR, BAUSHER ${ }^{2)}$ らは彼らの研究によつて少なくとも非刘称的 形状の加工においては, 特定の塑性異方性を持つ材料の ほうが成形性がすぐれているという事実を明らがし た.この塑性異方性を示す特性值としては, 板状試駼片 に引張変形を与えたときの幅方向の正と厚さ方向の廷の 比を考え，值*と呼えだ. 彼らの実験の範囲では，引張 変形の各段階で求めた $r$ 值を比較すると, 変形量の小さ い場合と最大荷重点におけるものとの間には差は認めら れず，破断した試料においてさえ破断䇢所から1"催れ た場所で求めた，值はほほ等しいという結果が得られ た**.

LANKFORD らの研究を简単に述べると次のとおりであ る. 46ロットの鋼板を使用して，実際にフェンダーをナ レス成形してその結果を整理し，成形性のよいグルーナ と悪いグループに分け，それらの銅板の機械的諸性質， $n$ 值, $r$ 值との相関を求めたところ，r值以外の因子に は大きな相違が認められなかつた， r值の内試料間の差 異が最も大きい压延方向の $r$ 值（ $\left.r_{L}\right)$ に注目すると Fig. 1 に示すような傾向を示し， $r_{L}$ の大きなものはプレス成 形性がよいことが明らかになつた，r值は等方性材料に おいては 1 に等しいはずであるから，，值がこのように 大きく変化するということは塑性異方性に影郘を及ほす 因子が大幅に変化していることを示するのである. その 因子の 1 つに結晶優先方位が考えられる.当然のことな

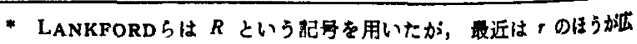
く用いられている。

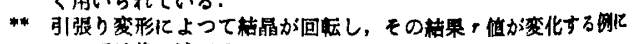
ついては後に述へる。 
がら，結晶異方性があれば磁気異方性を生じるふから， 板状試料においては磁気トルク曲線によつて異方性の有 無と程度を䉍単に測定できる。この研究に用いた銅板の 谱気トルク曲線は，Fig. 2 に示すような 6 個の型に大別 することができだ．さらに $\boldsymbol{r}_{L}$ 值と磁気トルク曲線の 型とを考虑してプレス成形性との関係を調べると， Fig. 3に示与ようになり，「ミ1·50あるいはトルク曲線が A 型のものは成形性がよく， A以外の型のものは成形性が 劣ることが明らかである.さらに加工硬化指数 $n$ をも考

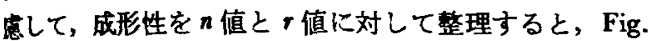

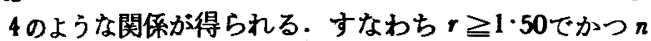
$\geqq 0.240$ のときに良好なプレス成形性が得られる.

以上の実舸から，特殊な塑性異方性を持つ材料は等方 生材料よりもプレス成形性がすぐれていることは明らか であが，さらに別の角度からの検討を行なつた：この 帘悇には，ほほ等しい機㭜的性質を持つ等方的である銅 板のロットX $\left(r_{L}=0.93, n=0.236\right)$ および好ましい望

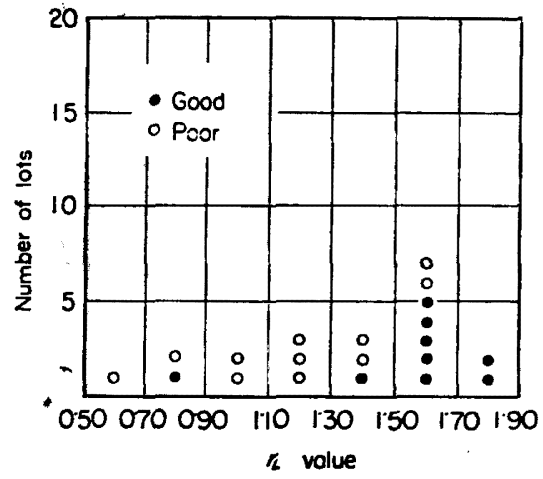

Fig. 1. Distribution of $r_{L}$ values for original group of twenty lots of known press performance. (LANKFORD et al.2))
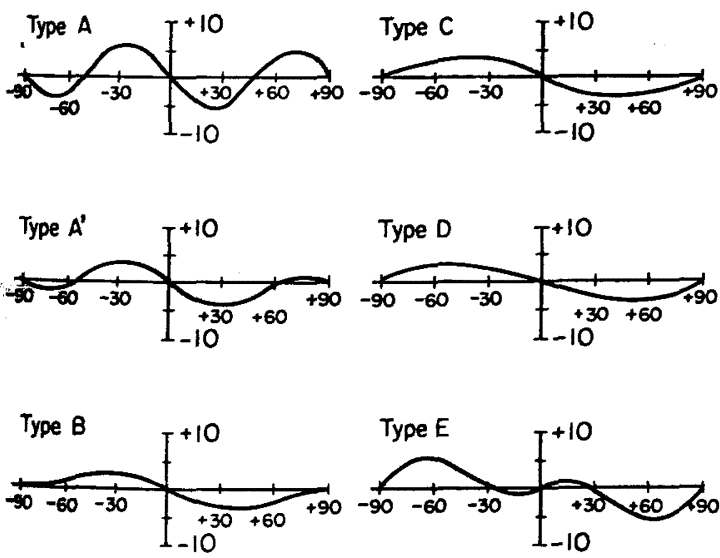

?ig. 2. Various types of magnetic torque curves observed in this investigation. (LANKPORD et al, ${ }^{2}$ )

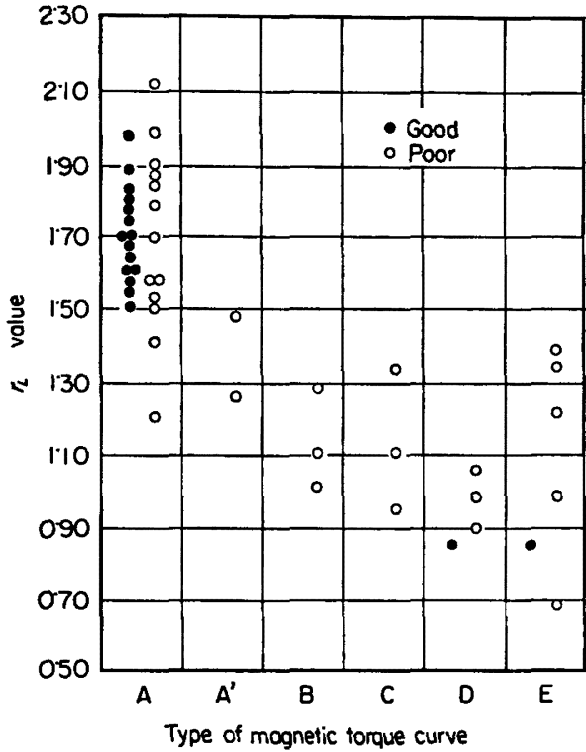

Fig. 3. Qualitative correlation between $r_{L}$ value and type of magnetic torque curve for all lots tested. (LANKFord et al. ${ }^{2}$ )

性異方性を持つロット $L\left(r_{L}=1 \cdot 56, n=0.252\right)$ を選え でフェンダーのプレス成形を行ない，長手方向に直角な 方向の歪を測定すると Fig. 5 に示すような分布が得ら れた。これによると， $r_{L}$ 值の大きいロット $L$ では直角 方向の疋は最大でも $25 \%$ に止まり，全数が破断せずに 成形できた．承最大の場所では長手方向巫と直角方向昰 の和もたかだか 40\%であつた．これに対して， $r_{L} \cong 1$ のロットXでは $18 \%$ が成形の際に破断し，成形できた ものの星分布は部分的に大きな差があり最大正は $40 \%$ で，その場所の長手方向および直角方向の歪の和は70\% にも達した.ロットXにおいては $n$ 值も0.236でロット $L$ に比して小さいか，，值の大きな差がこのような著 しいプレス成形性の相違に対応すると考えられる。

\section{$2 \cdot 2$ ランクフォード値と結晶方位}

BURNS, HEYER ${ }^{5}$ )は，低炭素鋼板について深絞り 性とほかの諸性質，たとえば機械的性質の異方性， 磁気的異方性，集合組織などとの関連をさらに詳細 に調ベた．特にリムド鋼およびキルド鋼板について 種々の熱処理を施し，極点図，磁父トルク曲線を克 明に検討して，\{111\} 面が板面に平行な優先方位成 分の多い試料ほどr值が大であることを明らかにし た。また，この事実を説明するために，次のような

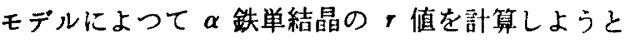
碔みた。

（a）过りは板面に平行な面，および板面に垂直 で压延方向を含む面内において，それぞれせん断応 力最大の方向に最も近い方向に生ずる. 
（b）その迄り方向における昰を板幅方向および板厚 方向に射影して，その正成分を求める.この幅雨および 厚さ正の比から值を求める.

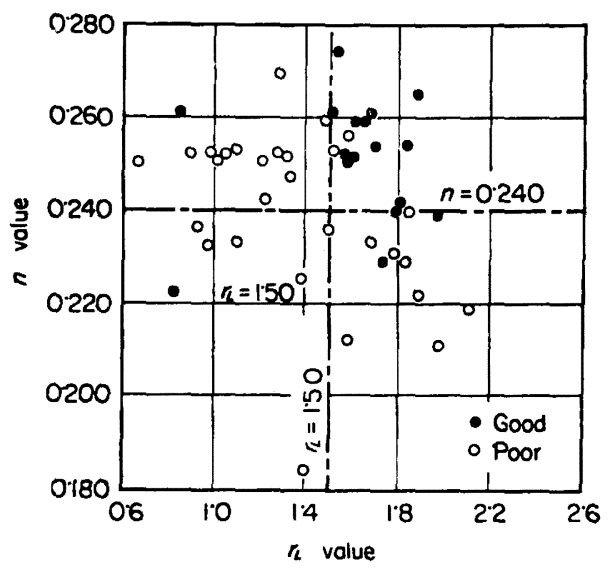

Fig. 4. $n$ value vs. $r_{\mathrm{L}}$ value for all lots tested. (LANKFORD et al.2))

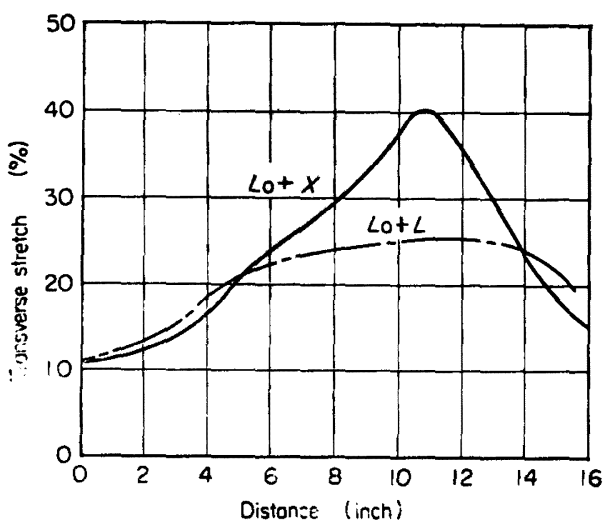

Fig. 5. Distribution of strains in fenders formed from trial lots $L$ and $X$. The sum of strains in the longitudinal and transverse directions are $40 \%$ for the lot $L$ and 70 $\%$ for the lot $X$. (LANKFord et al.2))

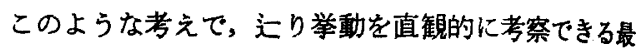
む簡単な 3 つの方位，すなわち立方体面が板面に平行 な “cube on face”之呼ばれる (100) [011] 方位, “cube on edge” と呼ばれる (110) [001] 方位, “cube on corner" と呼ばれる (111)[110] 方位について・值 を計算した・比較のため (100) [011] 方位が主方位であ る低炭素鋼の引張試験から求めた $r$ 值および主方位低 (110) [001] 方位を持つ珪素鋼板の r值をも測定して Table 1 に示した. 低炭素鋼板は $0^{\circ}$ 方向以外に引張つ たとき伸びが 1\%ほどしかなく、值が求められないが, $0^{\circ}$ 方向の $r$ 値もきわめて低い，珪素鋼の場合には， $0^{\circ}$ 方 向に比較して $90^{\circ}$ 方向の $r$ 值が著しく大きい。したが つて計算によつて求めたものと定性的には似た順向を示 していると言える。

以上の結果から薄鋼板においては，（a）(111)[1̄o] 方位が優先する集合組織を持つことが深絞性の点で社 ましく，(b) (110) [001] 方位のものは引張方向によつ で值が 1 からのまで変化するので異方性が著しいとい う点から好ましいとは言えず，(c)（100）[011] 万位性 全く好をしくないと推測することができる.この研究に おいては計算の内容は不十分であるが，集合組織を形成

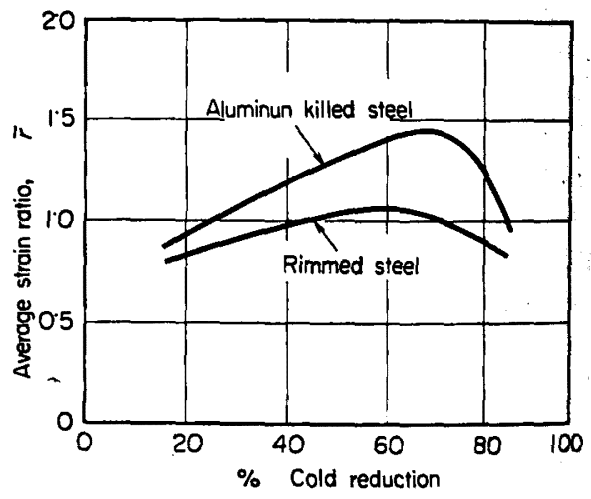

Fig. 6. The influence of the amount of cold reduction prior to annealing on the strain ratios of an aluminum-killed steel and a rimmed steel. (WhItELEY, WisE ${ }^{6}$ )

Table 1. Calculated $r$-value from orientation and observed $r$-value for oriented silicon steel and cold rolled low carbon steel.

\begin{tabular}{llll}
\hline Angle to rolling direction & $0^{\circ}$ & $45^{\circ}$ & $90^{\circ}$ \\
(100) [011] orientation & 0 & - & 0 \\
(110) [001] orientation & 1.0 & - & $\infty$ \\
(111) [110] orientation & 1.4 & 2.0 & 2.4 \\
$\begin{array}{l}\text { Oriented 3\% silicon steel } \\
\text { major component is (110) [001] }\end{array}$ & 0.22 & 0.14 & 10.5 \\
$\begin{array}{l}\text { Low carbon steel, cold } \\
\text { rolled } 60 \% \text { and annealed at } \\
850^{\circ} \mathrm{F}\left(455^{\circ} \mathrm{C} \text { ) for 90 min }\right. \\
\text { major component is (100) [011] }\end{array}$ & 0.50 & - & - \\
\hline
\end{tabular}




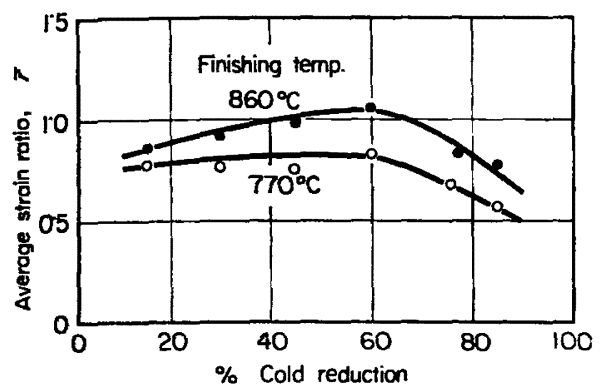

Fig. 7. The average strain ratio as a function of prior cold reduction for a rimmed steel finished at two different temperatures on the hot mill and coiled hot. The steel was cold-rolled in the laboratory and given a simulated box anneal. The composition of the steel was: $\mathbf{C}-0.03, \mathrm{Mn}-0.30, \mathrm{P}-0.010$, S-0.027, Al-0.005. The coiling temperature was between 650 and $693^{\circ} \mathrm{C}$.

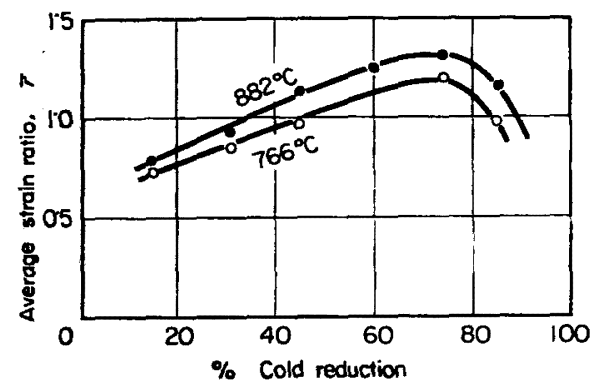

Fig. 8. The average strain ratio as a function of prior cold reduction for an aluminumkilled steel (A) finished at two different temperatures and coiled cold. The steel was cold-rolled in the laboratory and given a simulated box anneal. The composition of aluminum-killed steel (A) was: C-0.07, Mn-0.35, P-0.009, S-0.020, Al-0.07.

And the coiling temperature was between 554 and $570^{\circ} \mathrm{C}$. (WhITEley, Wise ${ }^{6}$ )

する方位成分を取り上げて，その系におけるえり变形か らて值を計算によつて求めることにより, 集合組織と $\boldsymbol{}$ 值との関係を定量的に 把握しようと試みた 功績は大き ‥

\section{3 ランクフォード値と压延条件}

WHTELEY，W WSE') は塑性異方性に及ほす压延条件の 影管を集合組幽との関連において明らかにした。冷延焼 鉵の・值に及ほす冷延圧下率の影響は Fig. 6 に示す とおりで, $\mathrm{Al}$ キルド銅は約 70\% の圧下率のとき r值 が最大となりリムド鋼も50〜70\% 付近で、值が最も 大きい.なおこの研究では $r$ 值俚面内の平均値索用い ている: 熱延仕上り温度も冷延㜔鈍板の $\bar{r}$ 值に影響を及

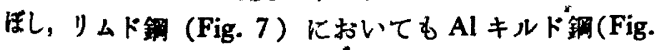

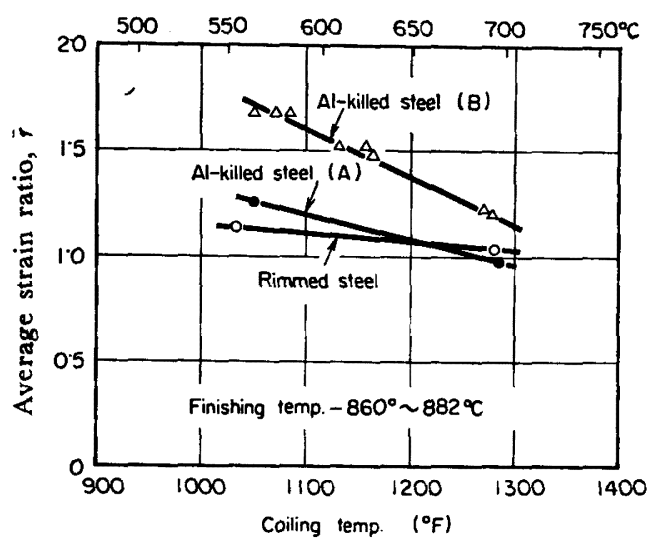

Fig. 9. The influence of coiling temperature on the average strain ratio of a rimmed steel and two aluminum-killed steels. The rimmed steel and aluminum-killed steel (A) are of the same compositions as those shown in Figs. 7 and 8, respectively. The composition of aluminum-killed steel (B) was: C0.06, $\mathrm{Mn}-0.33, \mathrm{P}-0.009, \mathrm{~S}-0.027, \mathrm{Al}-0.036$. The rimmed steel and aluminum-killed steel (B) were cold-reduced $60 \%$, and aluminumkilled steel (A) was cold-reduced $75 \%$ prior to annealing. (WhITELEY, WisE ${ }^{6}$ )
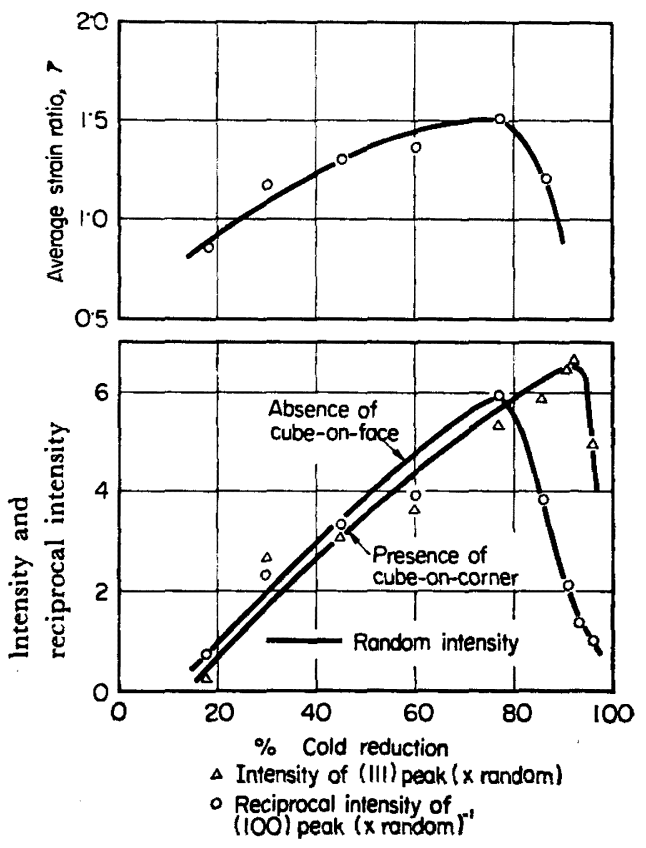

Fig. 10. Relationship between the changes in the average strain ratio with prior cold reduction and the changes in the final annealed texture as a function of prior cold reduction. (WhITELEY, WisE') 
8)においても仕上り温度が低いほど焼鈍板のテ值は低 い. 压延温度が $788^{\circ} \mathrm{C}$ 以下では特にてが低下するが， これは $\mathrm{Ar}_{8}$ 点以下ではフェライト相が生じこれが压延 されるためである．またりムド鋼においては，高温仕上

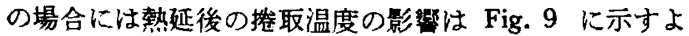
うにほとんどないが，Alキルド鋼の場合捻取温度が低い ほどて値は大きい。

冷延圧下率と主要優先方位の強さとの関係は Fig. 10 に示すとおりである．因には压下率と值との関係をも 併わせて示したが，(111) 面が板面に平行なときは高い r值を与えるので，その回折線の強さと，ランダム試料 の (111) 回折線強度の比を(111) 軸密度として税軸にと り，(100) 面が板面に平行なときはをを低下させるので (100) 回折線についてはランダム試料の回折線強度との 比の逆数を維軸にとつた．この四を見ると 3 つの曲線 は，いずれも压下率が堌加するにつれてほほ直線的に增 加し，極大値を示し，それ以上の圧下を加えると減少す る傾向を示す. 極大值を示す点はらと(100) 軸密度の逆 数は一致していて約 70〜75\% であるが，(111）軸密度 の極大値は約 90\% である.したがつて高いラ値を得る ためには (111) 軸密度を増すことと，(100) 軸密度を減 少させることとの 2 つの要因を同程度に重視することが 必要である.

上に述べたように熱延条件はて值に大きな影䅉を及ほ すので，当然集合組織にも影橥することが推測される．

Fig. 11 および Fig. 12 はリムド鋼および Al キルド銅 の集合組織に及ぼす熱延仕上温度の影響を示したもので ある・いずれの場合にも，仕上温度が高い之熱延のまま ではほほランダム方位に近ゔきこれを冷延焼鈍すると (111) 方位が増加して值が向上するか，仕上温度が低 い場合には熱延のままの材料の (110) 方位が強く,この 冷延焼鈍材の (111) の增加の程度は少ない。なお, 後に
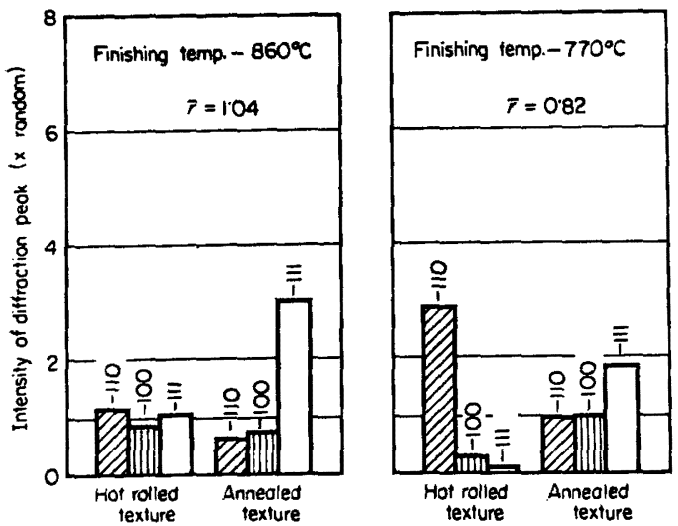

Fig. 11. Effect of finishing temperature on the hotrolled texture and subsequent cold-rolled $(60 \%)$ and annealed texture of a rimmed steel shown in Fig. 7 (WhIteley, Wise $\left.{ }^{6}\right)$ ).
述べるように熱延板においては板の表面層と中心首とで は集合組織は全く異なつていて，その後の冷延・焼鈛過 程における集合組織の变化を考光る場合には中心層の影 羿は無視できないが，この研究においては表面首に限ら れている.

\section{4 集合粗湍之面内異方性}

(i ）耳の発生と面内異方性

薄鋼板の成形性を論ずる際にはで值が重要であるとと るに，板面内の r值の変動 $\Delta r$ をも考虑する必要があ
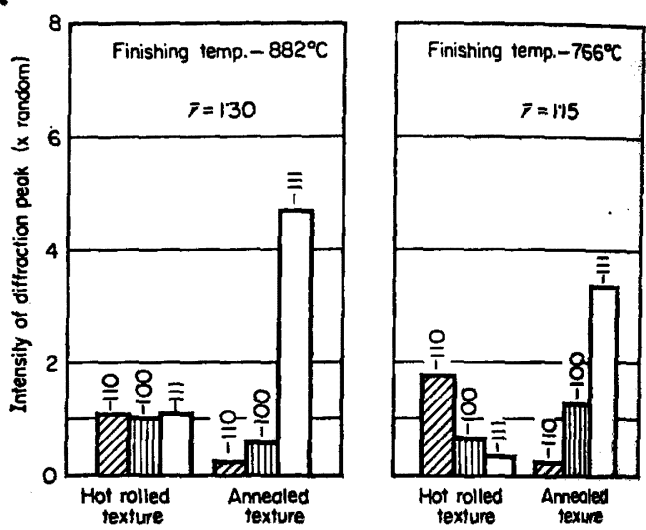

Fig. 12. Effect of finishing temperature on the hotrolled texture and subsequent cold-rolled (75\%) and annealed texture of aluminumkilled steel (A) shown in Fig. 8 (WHTTELEY, WisE ${ }^{6}$ )
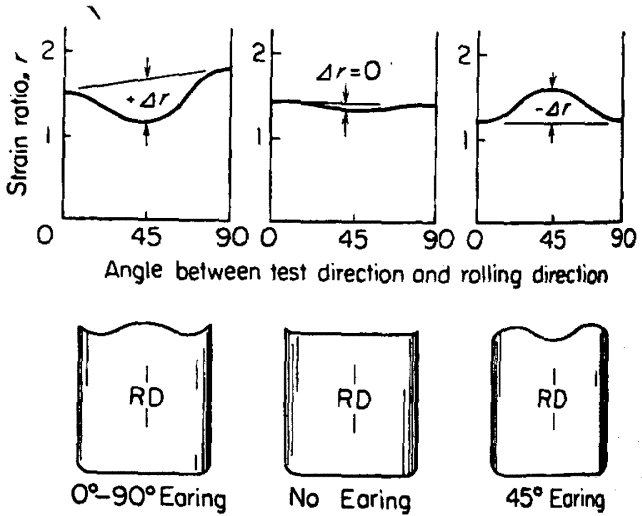

Fig. 13. Relationship between the variation in strain ratio with test direction and occurence of earing. If the strain ratio in the longitudinal and transverse directions is greater than the $45^{\circ}$ direction, then $\Delta r$ is considered positive as shown on the left. A material with a positive $\Delta r$ will form ears in the 0 and $90^{\circ}$ directions when drawn into a cup. A material with a negative $\Delta r$ as on the right will form ears $45^{\circ}$ to the rolling direction. Absence of earing is indicated by a $\Delta r$ of zero. (Whiteley, W WSE ${ }^{\text {) }}$ ) 


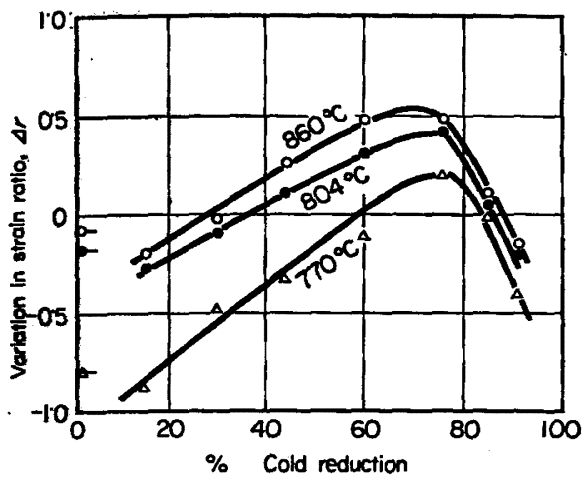

Fig. 14. The variation in $\Delta r$ as a function of prior cold reduction for a rimmed steel finished at the temperatures shown and coiled hot off the mill, as indicated in Fig. 7. (Whrteley, Wise')

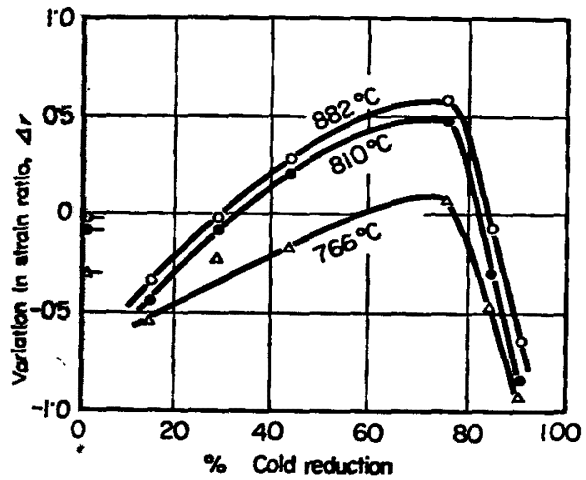

Fig. 15. The variation in $J r$ as a function of prior cold reduction for aluminum-killed steel (A) finished at the temperature shown and coiled cold off the hot mill, as indicated in Fig. 8 (Whiteley, W'SE')).

3. WhITELeY, WISE $\left.{ }^{6}\right)$ は $j r=\left(r_{L}+r_{T}\right) / 2-r_{D}$ とし, $\Delta r$ と深绞りの祭の耳の発生状況との間には Fig. 13 に模型 的に示すような関俰があることを明らかにした。ここに $r_{L}, r_{T}, r_{D}$ はそれぞれ压延方向に平行, 直角, $45^{\circ}$ 方向 のて值である.リムド銅における熱延仕上温度および命

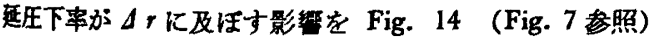
K，Alキルド銷における影䋨を Fig. 15 (Fig. 8 照)に 示した.これらによると，熱延仕上温度が低くなると $0^{\circ}$-900 の耳を生ずる圧下率の範囲が狭くなり，450の 耳を生ずる籍围が広がる。

(ii) ヤング象，ポアソン比と集合組織

结晶方位の影德を大きく受ける材料特性にヤング䒺, ’゚アソン比がある. 単結晶の主要方位のヤング事および ポアソン比は計算によつて求めることができる。伊藤，

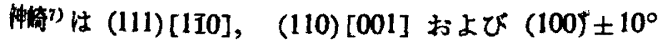

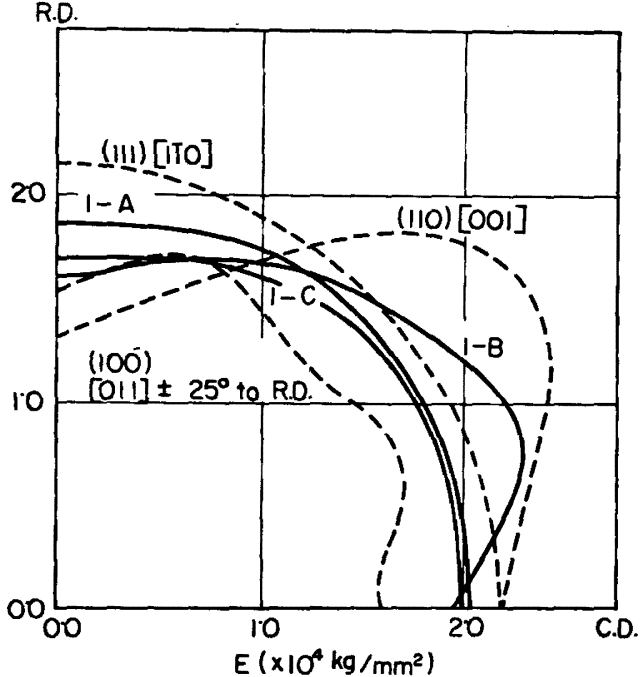

Fig. 16. Young's modulus of steel sheets tested and theoretically calculated value.

(ITO, KanzakI')

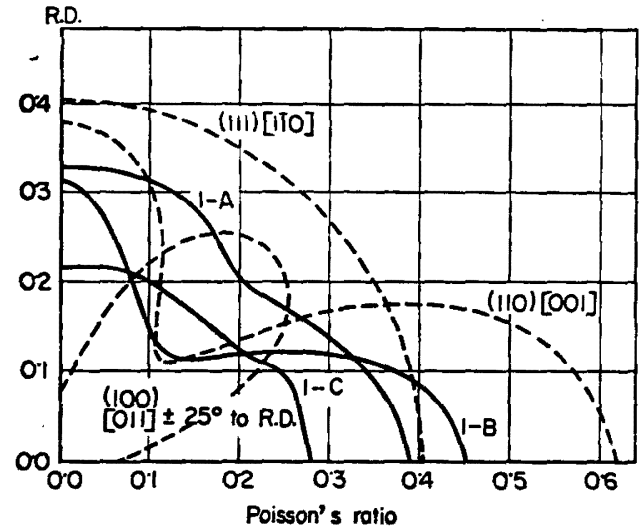

Fig. 17. Poisson's ratio of steel sheets tested and theoretically calculated value.

(Ito, KanZakI ${ }^{7}$ )

[011] $\pm 25^{\circ}$ の 3 つの方位について計算を行なうととも にこれらの方位を主方位に持つ極低炭素鋼板についての 実測を行ない，計算值との比较を試みた，その結果は Fig. 16，17 に示すとおりで，ヤング率の測定值は計算 值ほど著しい差異がないが，(110)[001]方位を持つＩ B 銅は面内異方性が最も大きく，(111)[110] 方位の I A 銅は面内異方性が最も小さいまた $(100)[011] \pm 25^{\circ}$ 方 位に近いI C 鋼は平均してヤング率が小さく，定性的傾 向はほほ一致していると言える.ポアソン比についても 全く同様で，測定值と計算值の面内異方性の傾向はよく 一致している. 


\section{3. 極軟鋼単結晶のランクフォード値}

(i) 著者らの研究

結晶の过り変形に基づいて薄鋼板の いう上述の BURNS，HEYER の着想に刺激されて，著者 $5^{8)}$ はさらに進えで $\alpha$ 鉄単結晶のr值を計算する一般的 方法を確立しょうと試みた。

まず極軟鋼の 3 つの过り面 $\{110\} ，\{112\} ，\{123\}$ 上で の臨界茄断応力はほほ等しいと仮定し，つぎに引張変形 に基うく試料断面の形状変化を以下にあげるような仮定 によつて起こると考えてみた（a）一度すべりが進行す ると加工硬化によつてその系に拈ける之りが困難になる までは他の系での主り注起こらない（b)引張り変形に よつて活動迄り方向は試料軸の方向に回転し, 沪り面は 試料の引張り方向およびシり方向に垂直な軸のまわりに 回転する.（c）したがつて試料断面においてうり面が回 転する軸の方向の寸法は不変であり，これに垂直方向に おける寸法変化が最大である. (d) 変形前後の試料の体 積は不変である.

このような仮定のもとに，板状試料に変形を与えた場 合を考える. 試料の長さ, 幅, 厚さをはじめにそれぞれ $l, w, t$, 变形後の寸法を $l^{\prime}, w^{\prime}, t^{\prime}$,昰みをそれぞれ $\varepsilon_{l}, \varepsilon_{w}, \varepsilon_{t}$ とする. $\varepsilon_{t}$ があまり大きくないときは

$$
\varepsilon_{t}=-\varepsilon_{l} \cos ^{2} \theta, \varepsilon_{w}=-\varepsilon_{l} \sin ^{2} \theta
$$

となるから，r值は次式で与えられる.

$$
r=\tan ^{2} \theta
$$

この考えによると，ｒ值はステレオ投影図を利用して 因上で簡単に求めることができる．14個の単結晶につい てこのような四式解法によつて求めた $r_{\mathrm{cal} l}$ と， その単 結晶を引張変形を行なつて測定した $r_{\text {obs }}$ を比较すると， Table 2 に示すようにかなりよく一致している.

(ii) VIETH, WhITELEY の研究

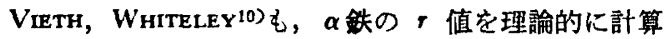

Table 2. Comparison of measured and predicted $r$-values for single crystal specimens of low carbon steel sheets.

\begin{tabular}{c|c|c|c|c}
\hline Specimen & $\begin{array}{l}\text { Strain in } \\
\text { tensile } \\
\text { direction }\end{array}$ & $r_{\mathrm{ob}}$ & $\theta\left(^{\circ}\right)$ & $r_{\mathrm{cal}}$ \\
\hline 1 & 9.7 & 1.14 & 46 & 1.04 \\
2 & 10.0 & 0.18 & 16 & 0.29 \\
3 & 10.0 & 0.13 & 16 & 0.29 \\
5 & 8.0 & 0 & 82 & 7.1 \\
8 & 10.0 & 0.36 & 6 & 0.10 \\
9 & 10.0 & 0.07 & 11 & 0.19 \\
10 & 10.0 & 0.07 & 10 & 0.18 \\
11 & 10.5 & 8.7 & 79 & 5.14 \\
13 & 10.0 & 0.20 & 13 & 0.23 \\
14 & 15.0 & 1.46 & 76 & 4.0 \\
19 & 10.0 & 0.72 & 26 & 0.49 \\
20 & 10.0 & $\infty$ & 35 & 0.65 \\
22 & 11.0 & 0.32 & 18 & 0.32 \\
29 & 10.0 & 0.23 & 26 & 0.49 \\
\hline
\end{tabular}

するために，次の仮定に立つて考察をすすめた，ます敘 の単結晶について，(a)試料は引張試験中一軸応力を受 ける.（b)歪は付加応力の方向に対して好ましい方向の 1つまたはそれ以上の活動立り系での迄りによつて生ず る. (c) 活動过り系は最大分解勏断応力の条件によつて 决定される.さらに変形の際の鉄単結晶の过りの様式に ついて下記の4つのモデルを設定した.

(a) 过り方向〈111〉，过り面 $\{110\} ，\{112\} ，\{123\} の$ 48個の过り系上で迄り変形が起こるが, 結晶の回転柱 視できるものとする.（これを 48SS, NR と略記する)

(b) 上記 48 個の过り系による変形の際の結晶回転 を考虑する.その結果到達する过り方向および方面が ともに応力方向に平行な最終方位をとるものと想定して 計算を行なう。ただし，実際にはこのような仮想の方位 は実現されず，他の过り系も活動して多重えりによる変 形が起こるはずであるが，ここでは計算の便宜のため一 応このモデルによる.(48SS, LR と略記)

(c) 过り方向〈111〉のペンシル逐りを考光，変形の 際の結晶回転は無視する。この場合の过り面は：亡り方 向を含み分解嵌断応力が最大の面である. (PG,NR)

（d）〈111〉方向のペンシル逐りで，変形に伴う結晶 回転を考虑する.（PG，LR）

以上の仮定およびモデルを基にして，引張変形による 試料の歪を IBM 1620 によつて計算し，值を求めると, Table 3 に示すようになる. この表では，さらに各䩚方 位の極軟鋼単結晶について引張試験によつて求めた 值 を示して，結晶方位から4つのモデルによつて推定した 值と比較対照している，単結晶の方位測定の讙差を考虑 して，推定值については $0^{\circ}$ および $\pm 3^{\circ}$ の 3 方向に引 張つた場合のr値を求めてある.これらの結果からどの モデルが最良かを求めることは困難であるが，48SS モ デルよりは PG モデルのほうがよく合うと言える.ま た結晶回転を無視した場合よりも大きな結晶回轱を教虑

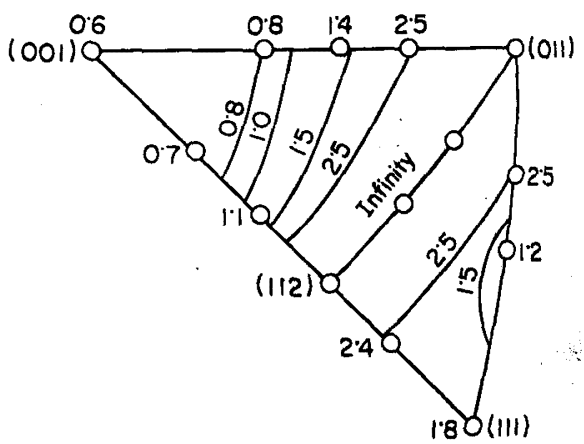

Fig. 18. Average $r$ value for the orientations noted in stereographic triangle as calculated for the assumption of pencil glide slip and large rotation (SS, LR). (VIETh, Whiteley ${ }^{10}$ ) 
Table 3. Comparison of measured and predicted plastic strain ratios $\times$ for single-crystal specimens of low-carbon sheet steel*.

\begin{tabular}{|c|c|c|c|c|c|c|}
\hline \multirow{3}{*}{ Orientation } & \multirow{3}{*}{$\begin{array}{l}\text { Measured } \\
r \text { values }\end{array}$} & \multirow{3}{*}{$\begin{array}{c}\text { Test } \\
\text { direction* }\end{array}$} & \multicolumn{4}{|c|}{ Predicted $r$ values for four assumptions about slip mechanism } \\
\hline & & & \multicolumn{2}{|c|}{48 Slip systems } & \multicolumn{2}{|c|}{ Pencil glide } \\
\hline & & & No rotation & Large rotation & No rotation & Large rotation \\
\hline$(001)[110]$ & $0 \cdot 000$ & $\begin{array}{r}-3 \\
0 \\
+3\end{array}$ & $\begin{array}{l}0.008 \\
0.000 \\
0.008\end{array}$ & $\begin{array}{l}0.116 \\
0.000 \\
0.116\end{array}$ & $\begin{array}{l}0.005 \\
0.000 \\
0.005\end{array}$ & $\begin{array}{l}0.074 \\
0.000 \\
0.074\end{array}$ \\
\hline$(17132)[1115]$ & $\begin{array}{l}0 \cdot 170^{* *} \\
0 \cdot 190\end{array}$ & $\begin{array}{r}-3 \\
0 \\
+3\end{array}$ & $\begin{array}{l}0.012 \\
0.017 \\
0.016\end{array}$ & $\begin{array}{l}0 \cdot 070 \\
0 \cdot 132 \\
0 \cdot 190\end{array}$ & $\begin{array}{l}0.031 \\
0.017 \\
0.007\end{array}$ & $\begin{array}{l}0 \cdot 177 \\
0 \cdot 132 \\
0 \cdot 087\end{array}$ \\
\hline (170) [7̄119] & $0 \cdot 333$ & $\begin{array}{r}-3 \\
0 \\
+3\end{array}$ & $\begin{array}{l}0.618 \\
0.086 \\
0.091\end{array}$ & $\begin{array}{l}0.930 \\
0.218 \\
0.270\end{array}$ & $\begin{array}{l}0.203 \\
0 \cdot 155 \\
0 \cdot 113\end{array}$ & $\begin{array}{l}0.451 \\
0.394 \\
0.337\end{array}$ \\
\hline$(160)[\overline{6} 124]$ & 0.445 & $\begin{array}{r}-3 \\
0 \\
+3\end{array}$ & $\begin{array}{l}1 \cdot 158 \\
1 \cdot 177 \\
1 \cdot 177\end{array}$ & $\begin{array}{l}1 \cdot 185 \\
1 \cdot 112 \\
1 \cdot 036\end{array}$ & $\begin{array}{l}0 \cdot 180 \\
1 \cdot 119 \\
1 \cdot 291\end{array}$ & $\begin{array}{l}0.424 \\
1.058 \\
1.136\end{array}$ \\
\hline$(1212)[1 \overline{4} 11]$ & $0 \cdot 625$ & $\begin{array}{r}-3 \\
0 \\
+3\end{array}$ & $\begin{array}{l}0.486 \\
0.505 \\
0.512\end{array}$ & $\begin{array}{l}0.635 \\
0.710 \\
0.783\end{array}$ & $\begin{array}{l}0.586 \\
0.505 \\
0.427\end{array}$ & $\begin{array}{l}0.765 \\
0.710 \\
0.653\end{array}$ \\
\hline$(001)[150]$ & $0 \cdot 780$ & $\begin{array}{r}-3 \\
0 \\
+3\end{array}$ & $\begin{array}{l}0.601 \\
0.615 \\
0.617\end{array}$ & $\begin{array}{l}0.711 \\
0.784 \\
0.855\end{array}$ & $\begin{array}{l}0.714 \\
0.615 \\
0.521\end{array}$ & $\begin{array}{l}0 \cdot 845 \\
0 \cdot 784 \\
0 \cdot 721\end{array}$ \\
\hline$(1111)[1 \overline{4} 31]$ & $0 \cdot 787$ & $\begin{array}{r}-3 \\
0 \\
+3\end{array}$ & $\begin{array}{l}0 \cdot 688 \\
0.390 \\
0.385\end{array}$ & $\begin{array}{l}0.934 \\
0.581 \\
0.638\end{array}$ & $\begin{array}{l}0.542 \\
0.450 \\
0.507\end{array}$ & $\begin{array}{l}0.736 \\
0.671 \\
0.704\end{array}$ \\
\hline$(150)[001]$ & $1 \cdot 130$ & $\begin{array}{r}-3 \\
0 \\
+3\end{array}$ & $\begin{array}{l}2 \cdot 335 \\
0 \cdot 999 \\
2 \cdot 335\end{array}$ & $\begin{array}{l}1 \cdot 631 \\
1 \cdot 000 \\
1 \cdot 631\end{array}$ & $\begin{array}{l}2 \cdot 048 \\
0 \cdot 999 \\
2 \cdot 048\end{array}$ & $\begin{array}{l}1.431 \\
0.999 \\
1.431\end{array}$ \\
\hline (111) [112] & $\begin{array}{l}2 \cdot 030^{* *} \\
2 \cdot 400\end{array}$ & $\begin{array}{r}-3 \\
0 \\
+3\end{array}$ & $\begin{array}{l}3 \cdot 252 \\
3 \cdot 000 \\
3 \cdot 252\end{array}$ & $\begin{array}{l}1 \cdot 371 \\
1 \cdot 224 \\
1 \cdot 371\end{array}$ & $\begin{array}{l}5 \cdot 626 \\
6 \cdot 000 \\
5 \cdot 626\end{array}$ & $\begin{array}{l}2 \cdot 371 \\
2 \cdot 449 \\
2 \cdot 371\end{array}$ \\
\hline$(195)[1321]$ & $2 \cdot 950$ & $\begin{array}{r}-3 \\
0 \\
+3\end{array}$ & $\begin{array}{l}11 \cdot 546 \\
11 \cdot 572 \\
19 \cdot 458\end{array}$ & $\begin{array}{l}2 \cdot 946 \\
2 \cdot 792 \\
4 \cdot 465\end{array}$ & $\begin{array}{l}15 \cdot 360 \\
17 \cdot 171 \\
18 \cdot 983\end{array}$ & $\begin{array}{l}3 \cdot 919 \\
4 \cdot 143 \\
4 \cdot 357\end{array}$ \\
\hline$(1272)[8 \overline{1} \overline{4} 1]$ & $5 \cdot 681$ & $\begin{array}{r}-3 \\
0 \\
+3\end{array}$ & $\begin{array}{l}14 \cdot 946 \\
14 \cdot 850 \\
14 \cdot 586\end{array}$ & $\begin{array}{l}2 \cdot 682 \\
2 \cdot 822 \\
2 \cdot 954\end{array}$ & $\begin{array}{l}31 \cdot 058 \\
27 \cdot 688 \\
24 \cdot 369\end{array}$ & $\begin{array}{l}5 \cdot 771 \\
5 \cdot 262 \\
4 \cdot 936\end{array}$ \\
\hline$(334)[\overline{9} 16]$ & $7 \cdot 535$ & $\begin{array}{r}-3 \\
0 \\
+3\end{array}$ & $\begin{array}{l}6 \cdot 674 \\
6 \cdot 779 \\
6 \cdot 804\end{array}$ & $\begin{array}{l}2 \cdot 209 \\
2 \cdot 104 \\
2 \cdot 030\end{array}$ & $\begin{array}{r}9 \cdot 123 \\
10 \cdot 378 \\
11 \cdot 227\end{array}$ & $\begin{array}{l}3 \cdot 020 \\
3 \cdot 221 \\
3 \cdot 350\end{array}$ \\
\hline
\end{tabular}

- The above predictions represent: (a) The crystallographically defined test direction, $0^{\circ}$, and (b) two additional directions, each $3^{\circ}$ from this test direction.

- Two specimens cut from one crystal.

したモデルのほうがよく合うことも明らがである.ただ し引張り変形が 10〜20\% 程度の場合には結晶回転はさ 怯ど大きくはないと考えられる。

最す刻定值に近い, 值を与えるモデル(d)によつて， 板面任平行な 14 の異なる方位を持つ単結晶の值を計 算住よて求めると Fig.18 亿示すようになる.この四 では (011)-(123)-(112) 老結ら゙線上でラが市になつて いるが，乙れ性面内各方位のr值を単に算術平均したた

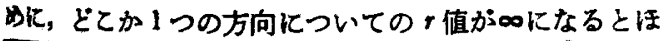

かの方向のr値のいかんにかかわらずテはめとなつたも のである.「值をこのようにして求めることは妥当では なく，後に述へる $D$ 值 ${ }^{11}$ のような数値に換算してから平 均を求めるような手法によることが必要である。

上述のモデルによつて, 主要な方位(011) [110], (111) [110]，(011)[100] および (112)[110] に関する r值の 引張方向による変化を計算で求めた結果を Fig. 19～22に 示した. 上述の著者らのモデルは内容的には VIETH, WHITELEY のモデル $(\mathrm{c})$ に等しいのて，著者らの求めた $r$ 值の面内の㚆化もこの Fig. 19〜22 の PG, NR と全 


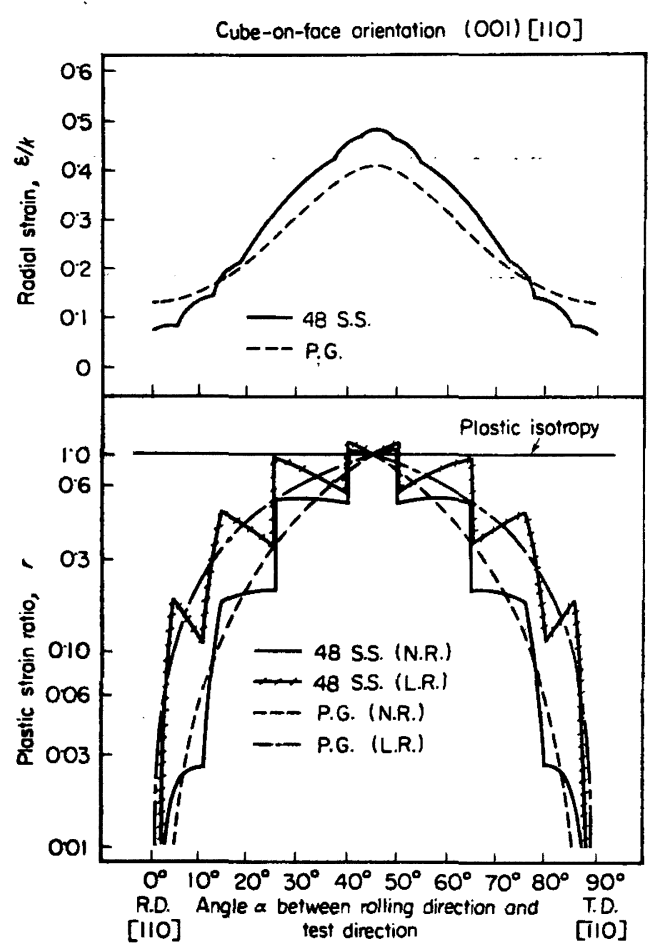

Fig. 19. Plastic strain ratio $r$ and radial strain $\varepsilon / k$ for the orientation (001) [110] calculated for various directions in the plane of the sheet assuming different slip mechanisms. (VIETH, Whiteley ${ }^{10}$ )

く一致した結果が得られた日). なおこれらの図中に示さ れた $\varepsilon / k$ は絞りの際に生ずる半径方 向隶の計算值で, 円筒絞りの際の耳発生に対応する值である.

これらの単結晶に閉する計算結果からは，集合組織を 持つ多結晶体試料の值を直接求めることはできないが， 少なくとも「值を向上させるためにどのような優先方位 成分を選択すべきかの明確な基準を得ることができる.

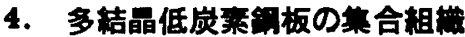

\section{1 冷延集合粗流}

まず冷延集合組織について述べることとする，低炭素 鋼および珪菜銅多結晶体の命延集合組織は，1930年代す でにX線回折写真法によつて求めた極点四に基づいて解 析が行なわれ，(1) (100) [011] 方位（Fig. 25 に示した A方位) から [011] 軸のまわりに回転して (211) [011] 方位 (D) に至る方位を含む優先方位の系列 (A-B-C -D)，(2）(111) 面が压延面に平行で (111) [011] 方位 (E) から (111) [112] 方位 (F) に至る方位を含む優 先方位の采列 (E-F-E-F) の 2 系列が存在すること が明らかにされている1)8)12). 最近X線ディフラクトメ 一ター法により極点図および反転極点図が定量的に測定

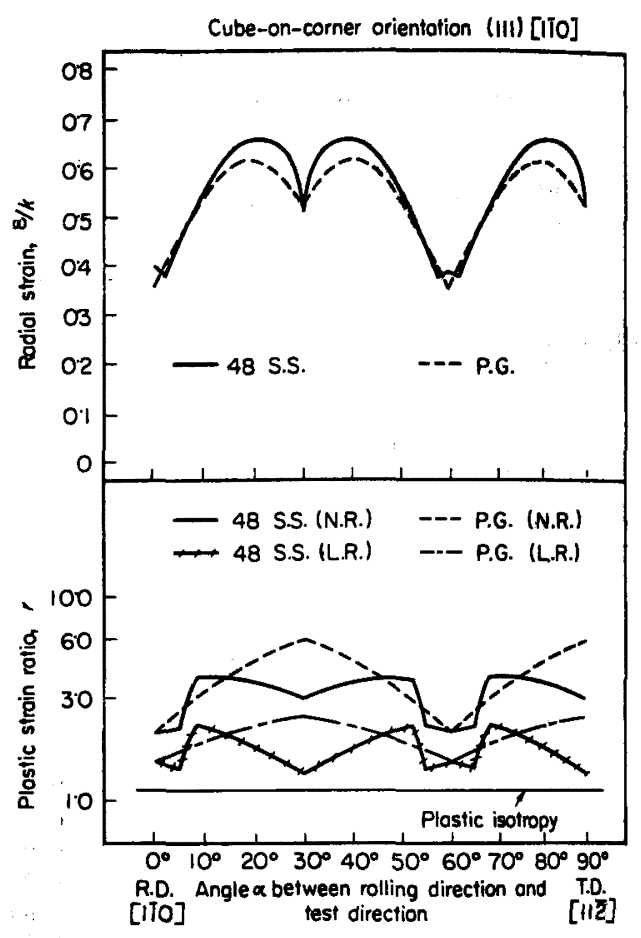

Fig. 20. Plastic strain ratio $r$ and radial strain $\varepsilon / k$ for the orientation (111)[1I0] calculated for various directions in the plane of the sheet assuming different slip mechanisms. (VIETH, Whiteley ${ }^{10}$ )

されるようになり，優先方位成分についての再検討か行 なかれ従前とは異なる新しい解釈も報告されている。る の1つは，(3)板面法線から压延方向に 30〜350頋いた 〈110〉軸を織維軸とする優先方位系列1816)でり，(4) ほかの 1 つは(001)面が圧延面に平行で〈001〉軸のまわり に回転した方位成分を持つ優先方位系列15である.

これら新しい系列の中（3）の系列は上述(1)，(2) の系列の重被によつても十分説明できるものでありり, この系列が生ずる必然性も考えにくい1216)（4)の系列 は写真法では測定できなかつたものが，X線ディフラク トメータ法によつて定量的に検知されるようになつだ のと考えられる.

冷延集合組織の 1 例として70\%冷延した鋮板の $\{110\}$ ， $\{100\},\{111\}$ 極点园犺を Fig. 23 K, 同じ鋼板の板面法 線方向 (ND), 压延方向 (RD), これらに直角な方向 (T D)に関する反転極点困》を Fig. 24 に示した.これ らの図加らも上記 (1)，（2），(4)の優先方位系列性存 在するが，(3)·の系列については否定的であることがが かる.

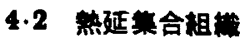

熱延板においては， $A_{8}$ 変態点以上でオーステナイト 相中に生じた圧延組織は冷却途中フェライトに变態する 


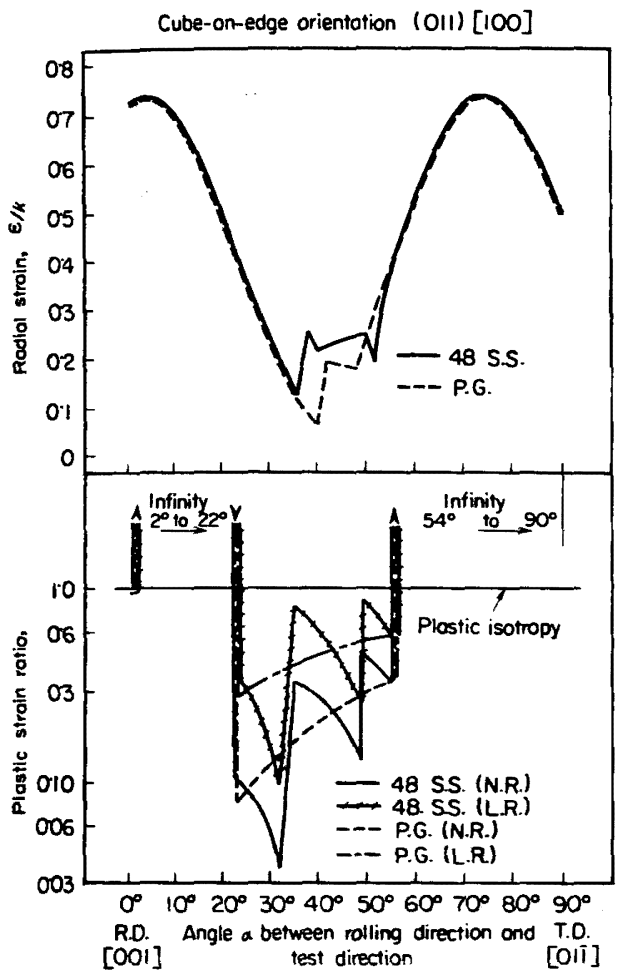

Fig. 21. Plastic strain ratio $r$ and radial strain $\varepsilon / k$ for the orientation (011) [100] calculated for various directions in the plane of the sheet assuming different slip mechanisms. (VIETH, Whiteley'i0)

ときにランタム化し，一部温度が下つてフェライトが生 しそれが压延されて生じた压延組織も冾却する途中に再 洁晶を行なつて変化するなど，温度の影響を大きくう け，板の表面と中心では集合組織に大きな相違がある。 このような板の外面の相達に注目した研究は少ないが 従来の研究結果ををとめると67)17)18）板の表面層に関し ては,

(a) $760 \sim 800^{\circ} \mathrm{C}$ の比较的圧延温度が低い場合には， (1) (110)[001] が主方位であり，(2） (211)[1111]を [111] 軸まわりに $\{321\}[111]$ 方位まで回転した方位を 含む系列が主方位であり，

(b) 圧延温度が高くなるとランダム方位が增加す る。た板の中心層については

(c) (100) [011] 方位およびこれから [011] 軸まわ 比 211\}[011] 方位をで回転した方位を含む系列が主 方位になつている，この方位は圧 延温度が低いほど多 く，高いほど隇少する. Fig. 25 にストリップ球した リムド銅（熱正仕上温度 $830^{\circ} \mathrm{C}$, 挖取温度 $620^{\circ} \mathrm{C}$ ) の 表面首および中心首の極点因河を，Fig. 26 に同一試料 の反轱極点図の゙示した．これらの図から表面㡟と中心 危の集合組織の相違が一目でわかるであろう。

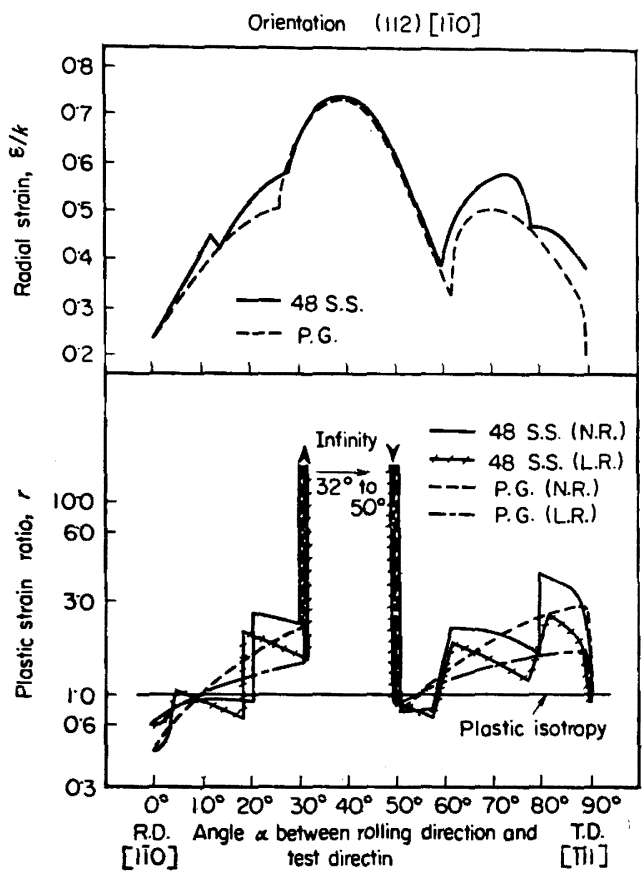

Fig. 22. Plastic strain ratio $r$ and radial strain $\varepsilon / k$ for the orientation (112) [110] calculated for various directions in the plane of the sheet assuming different slip mechanisms. (VIETH, Whiteley ${ }^{10)}$ )

\section{$4 \cdot 3$ 再結晶策合粗䋨}

これについても，すでに 1930 年代に KURDJUMOV, SACHS $^{19)}$ および GENSAMER, LUSTMAN ${ }^{20)}$ はX線回折写真 法によつて極点図を求め，以上にあげる 3 種類の優先方 位，すなわち，(1) 圧延面に（100）面が平行で [011] 軸が圧延方向から左右に約 $15^{\circ}$ 頭をふつた方位，(100) $[011] \pm 15^{\circ}$ ，(2) (111)[112] 方位, (3) (112) [110]土 $15^{\circ}$ 方位の 3 主方位があることを示した。これについて も，最近 $\mathrm{X}$ 線ディフラクトメーターによる定量測定によ つて極点図, 反転極点図を求再検討が行なわれた。

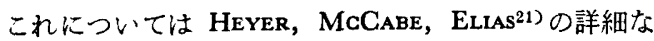
研究があり，圧下弯をかえて冷延を行ない焼鈍を行なつ たものの主な方位は次のようになつた。

(a) リムド鋼， $40 \sim 70 \%$ 冷延， $688^{\circ} \mathrm{C}$ 焼鈍， 主方位(111) [110](E), 副方位 (110) [001](G)

（b）キルド鋼， $70 \%$ 冷延， $738^{\circ} \mathrm{C}$ 焼鈍， 主方位(111) [110] (E) + (111) [112] (F)

（c）リムド鋼，80\% 冷延， $688^{\circ} \mathrm{C}$ 焼鈾, 主方位(111) [110] (E)

（d）リムド鋼，85\% 冷延， $688^{\circ} \mathrm{C}$ 焼鈍， 主方位(111) [112](F) + (111) [110] (E)

(e)りムド鋼, 90\% 冷延, $688^{\circ} \mathrm{C}$ 焼釚, 主方位(111)[112] (F), 副方位 (111) [110] (E) 

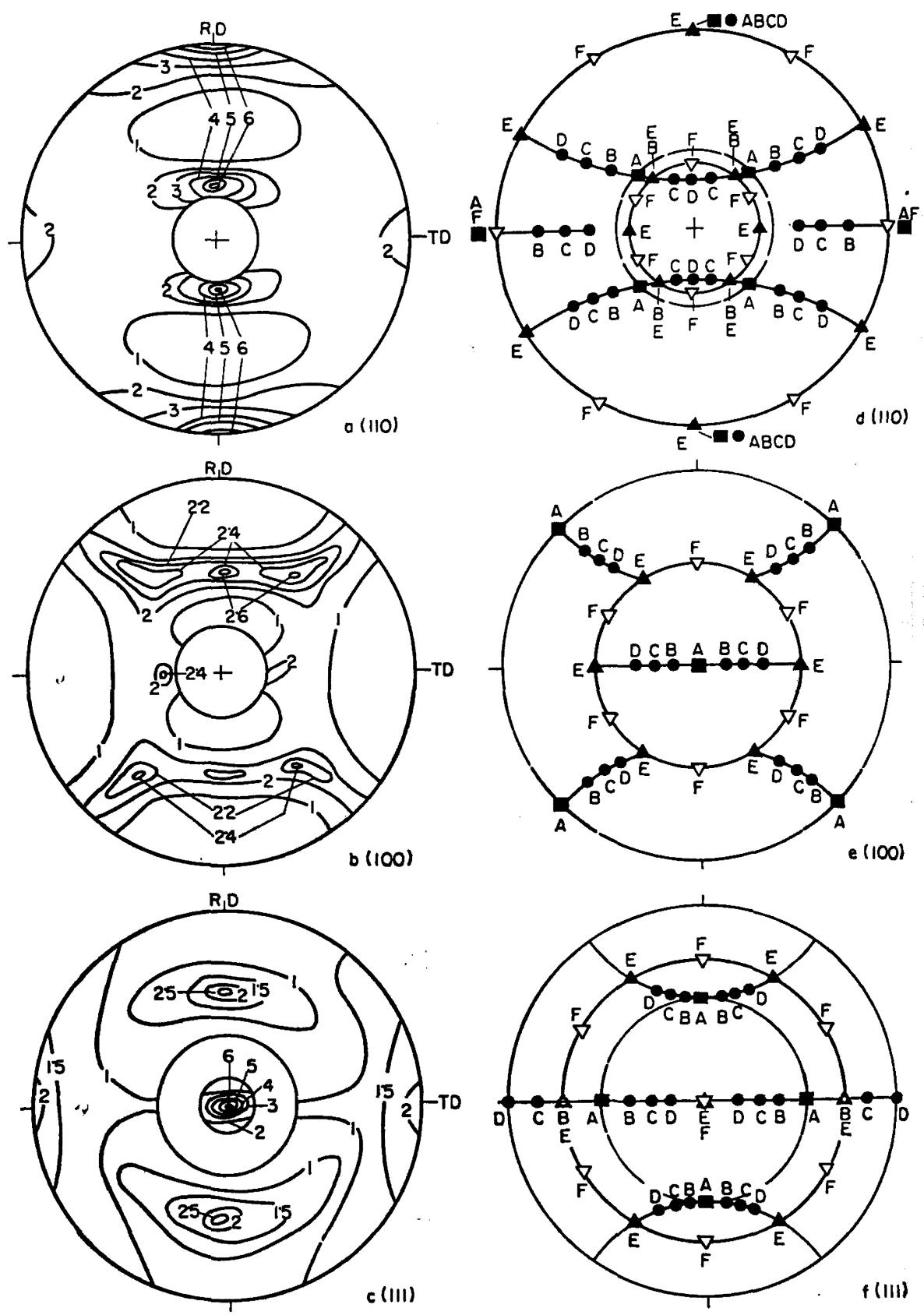

Fig. 23. (110), (100) and (111) pole figures of low carbon steel sheet cold-rolled $70 \%$.

Key for the orientation A, B, ...., F is shown in Fig. 25. 

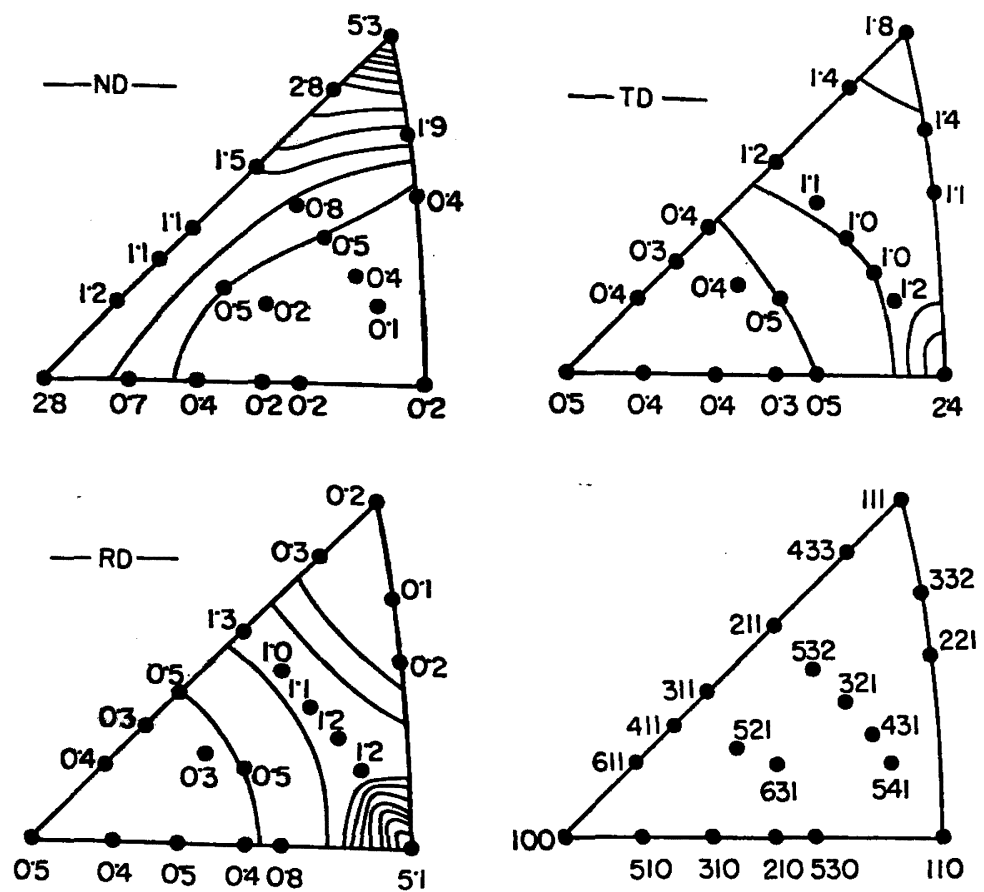

Fig. 24. Inverse pole figures of the same specimen shown in Fig. 23.

(f) リムド鋼, $97 \cdot 5 \%$ 冷延, $688^{\circ} \mathrm{C}$ 焼鈍, 主方位 (100) [012] (M), 副方位 (111) [112] (F)

なお（a）については主方位として (110) [001](G) の 功強く生じている測定結果があり 22)，また（d）には

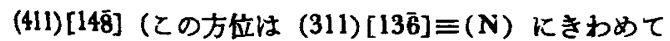
近い方位である) が認められている922).

梂低炭素 $\mathrm{Al}$ キルド鋼の $70 \%$ 冷延後 $700^{\circ} \mathrm{C}$ で $4 \mathrm{hr}$ 稓釚したるのの極点四および反転極点图を Fig. 27 およ び Fig. 28 にそれぞれ示した。これらの図には(111) [110] 方位 (E), (111) [112] (F) 方位から (111)〈321〉 方位 (K) への回転関係にある方位の系列, (332) [110] 方位 (L) 加ら (111) [110](E)を経て (112)[110](D) に至る方位の系列などが認められる・同じ鋼について90 \%令延し $800^{\circ} \mathrm{C}$ で $4 \mathrm{hr}$ 焼鈍したものの極点図および反 枟楚点四をそれぞれ Fig. 29 および Fig. 30 に示した. 上記 (e) の主・副方位 (EおよびF) のほかに (100) [011] $\pm 18^{\circ}$ ，すなわち (100) [012] 方位および (411)

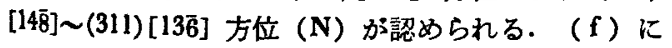
速べてあるように 97·5\% の冷延圧下を加えるときは主 方位と副方位の強度は反転して (100) [011] $\pm 18^{\circ}$ 方位 (M)漒くなる例を Fig. 31 亿示した。

\section{5. 多結晶低宸素銅板の $\mathbf{r}$ 值}

5.1 板のr值をその柾点图から図上で推定する方法
すでに述べたように $\boldsymbol{\alpha}$ 鉄単結晶の薄板については，そ のr值をどのような方位についても計算によつて推定す る方法が提案された．したがつて前節に述べた各種薄板 の集合組織の主方位が実験で求められれば，その板の， 值忹ほほ推測できる．さらに進んで定量的にｒ值を求め る方法が研究されているが，ELIAS，HEYER，SMTTH'11は 実豎的に求めた (111) 極点図を利用して直接 $r$ 値を求め ようと試みた。それは次のような方法によつている。

(i) 等 $r$ 值網

$\alpha$ 鉄においでうり面とうり方向の組合せを考えると， 3 個の $\{110\}$ 次り面, 3 個の $\{112\}$ 逐り面, 6 個の $\{123\}$ 汇り面および 4 個の〈111〉汇り方向があるので, 計48の 㫐り系がある.しかし引張変形に伴う結晶の幅および 厚さ方向の形状変化を論ずるためには，活動シり方向の みを知れば十分で活動过り面がどれであるかは考虑しな くてよいという，上述 VIETH らのペンシルううりモデル によつて考察をすすめる. 汇り系がきまれば, 引張变形 による試料形状変化は，引張軸に垂直な投影面に対する 活動过り方向の射影と，厚さ方向の軸のなす角 $\theta$ によつ

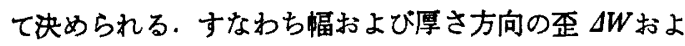
び $\Delta T$ は

$$
\begin{aligned}
& \Delta W=\sin \theta \\
& \Delta T=\cos \theta
\end{aligned}
$$

で表わされると考光，r值は次式で表わされると仮定す 

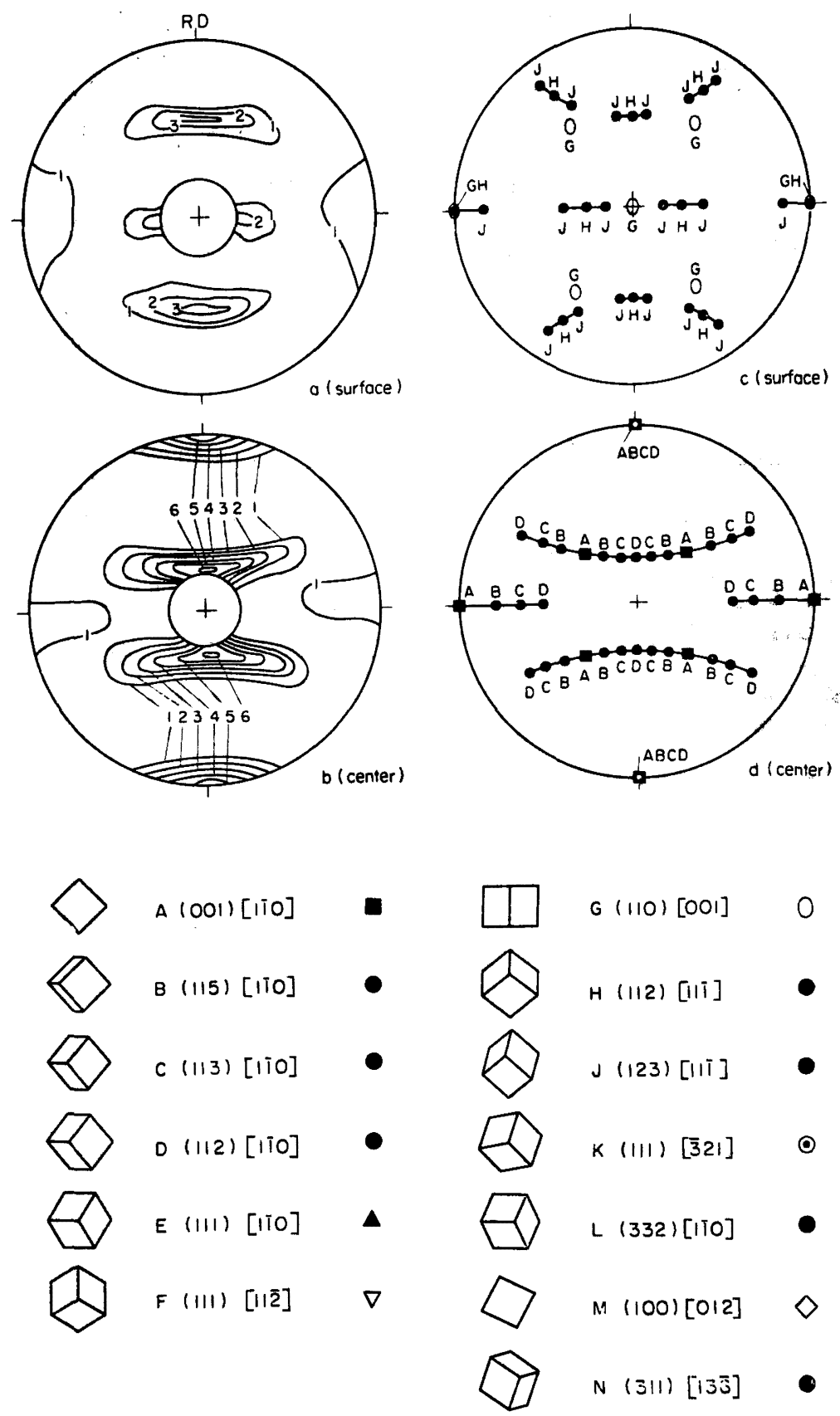

Fig. 25. (110) pole figure of hot rolled low carbon steel sheet. Finishing temperature was $830^{\circ} \mathrm{C}$ and coiling temperature was $620^{\circ} \mathrm{C}$. 

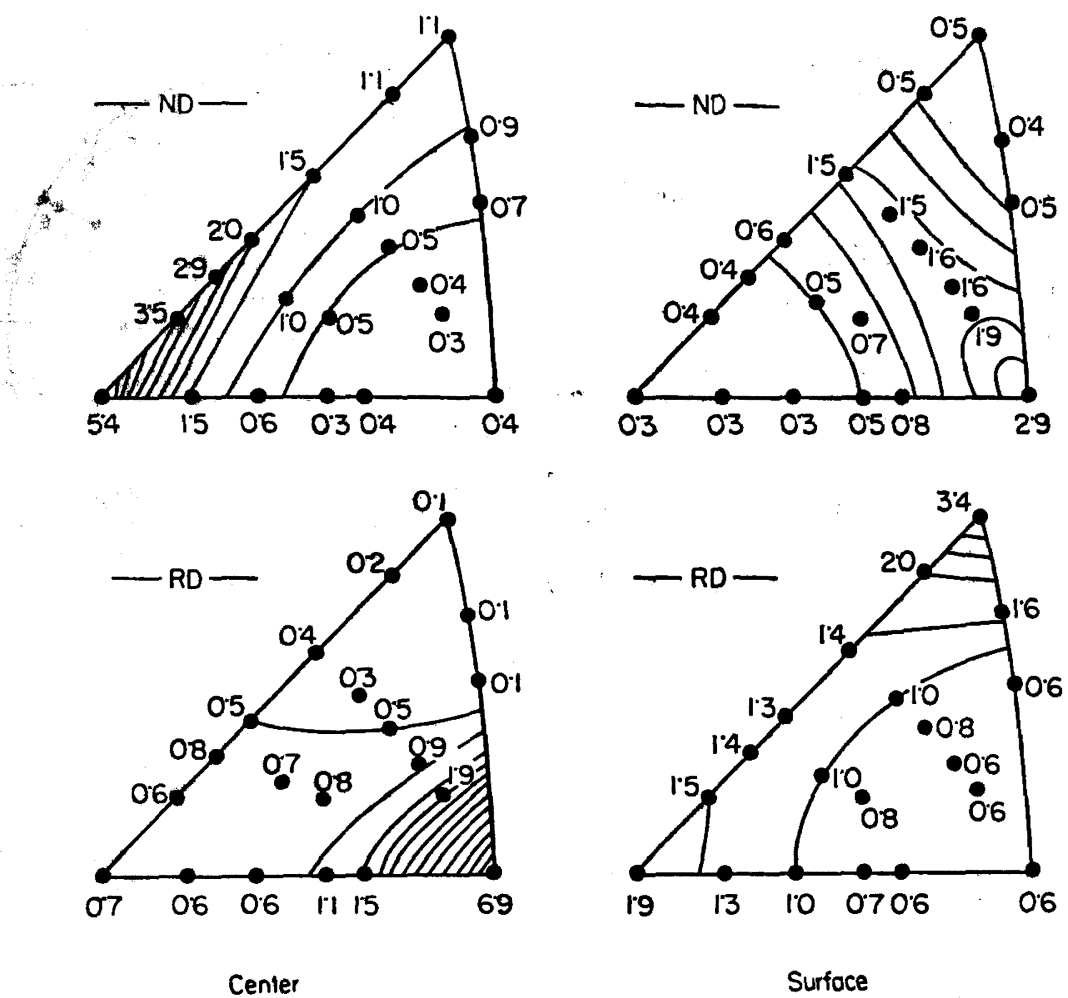

Fig. 26. Inverse pole figures of the same specimen shown in Fig. 25.

る.

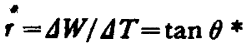

一方，ステレオ投影図において板面法線を投影円の中 心炕とり，板蝠方向を水平方向におくと図の同一子午線 上に極を持つ达り方向はすべて $\theta$ が等しく，したがつて 等しいr值を持つ.このようにして等、網を作ることが できる.

他方試料における最大剪断応力は試料軸のまわりの $45^{\circ}$ の円雓面に生ずる. それゆえ極点図で示せぼ引張軸 の極から $45^{\circ}$ の位置にあたる緯度線が䇋断応力最大の 位置を示すことになる. それゆえ, 銅板の $\{111\}$ 極点図 を作つておき，それにこの等 $r$ 値網を重ねてみると，顡 断応力最大でかつ、値の大きい領域に軸密度の集積の大 きいほど，その板の 值が大きくなることがわかる．た だし、値は 0 からのまで変化するので，等，值網を用い ても(111) 軸密度の分布に応じた $r$ 值の平均を求めるこ とができなくなるおそれがある。

(ii) $D$ 值の設定

r値における上述の久点を避けるため，ELIAsら ${ }^{11) ~ は ~}$ 次式で与えられるD值を導入した。

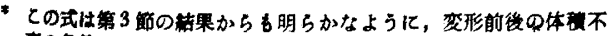
変の条件を满足しない点に僬点がある。とのととはHOSFORD ${ }^{23}$ 指持している。

$$
D=\frac{\Delta W-\Delta T}{(\Delta W+\Delta T) / 2}=2\left(\frac{\Delta W-\Delta T}{\Delta W+\Delta T}\right)
$$

ただし， $\Delta W ， \Delta T$ はそれぞれ幅方向および板厚方向の 兲である.この $D$ 值は，等方性材料においては $\Delta W=$ $\Delta T$ であるから $D=0$ であり, $\Delta T=0$ のとき $D=2$, $\Delta W=0$ のとき $D=-2$ となつて 2 と -2 との間で変化 し，值が正のときは深絞り性がよく負のときは悪いこと を示す．また，值とD值との関係は次式で表わされる.

$$
r=\frac{2+D}{2-D}, \quad D=\frac{2 r-2}{r+1}
$$

この $D$ 值を用いて，上述と同様の等 $D$ 值網を作ると Fig. 32 のようになる。この図を(111) 極点因に重ねる と薄銅板のr值を求めることができる．それには極大值 を求める方法と, ある角度範囲の強度の平均を求める方 法とが考えられる.

\section{(a) 極大笽法}

苏断応力最大の位策， $\mathrm{S}_{\mathrm{MAx}}$ を記入した等 $D$ 値網を Fig. 33 に示すように(111)極点図に重ね合わせ， $\mathrm{S}_{\mathrm{MAx}}$ 線上の軸密度と $D$ 值を読み取り，軸密度に応ずる重みを 考虑して $D$ 值の平均を求める方法である。この四恃压延 方向の値 $D_{L}$ を求めている場合を示しているが，等 $D$ 值 網の矢印を引張軸の方向に合わせると, 望む方向のr值 

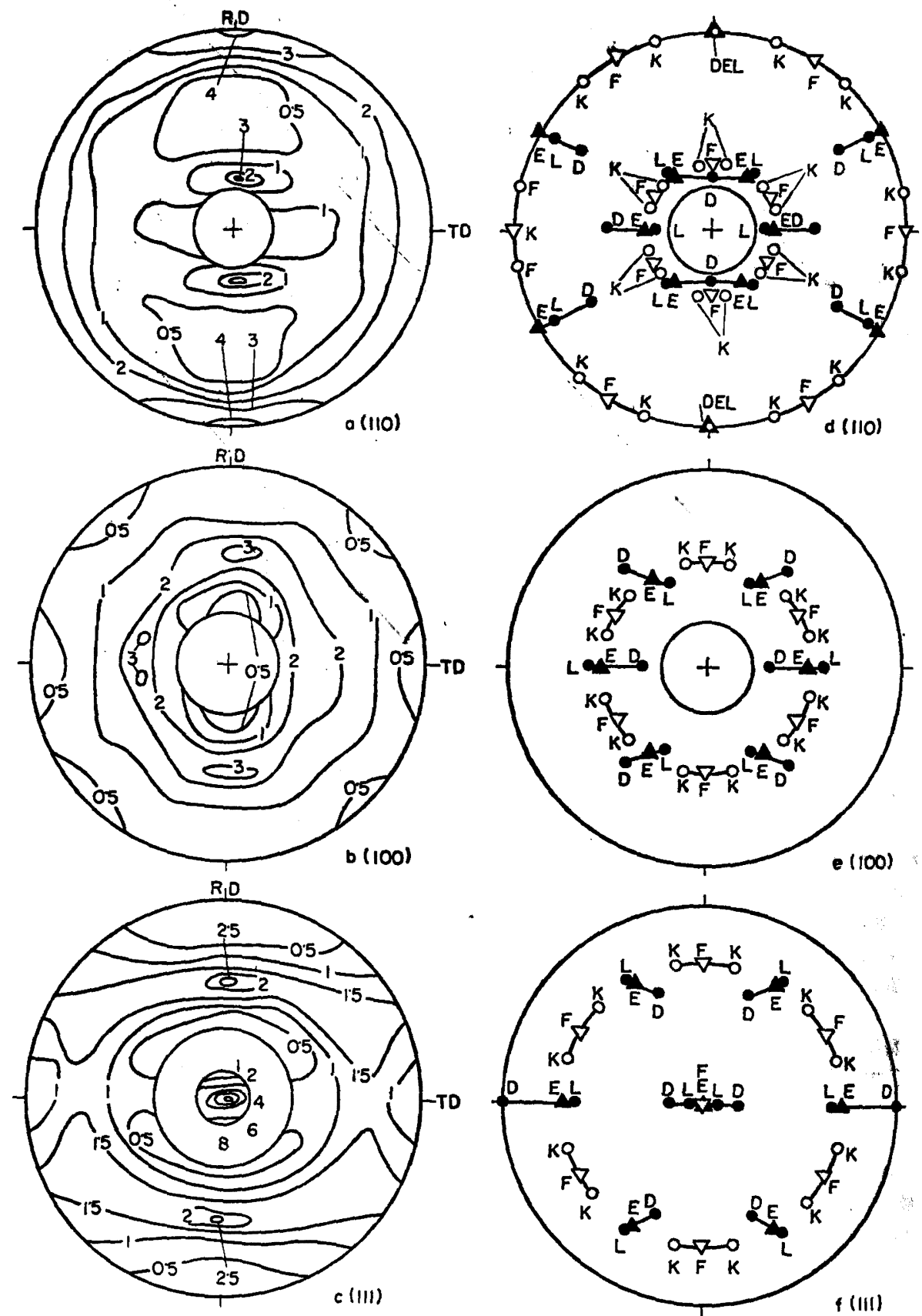

Fig. 27. (110), (100) and (111) pole figures of low carbon steel sheet cold-rolled $70 \%$ and annealed at $700^{\circ} \mathrm{C}$ for $4 \mathrm{hr}$. 

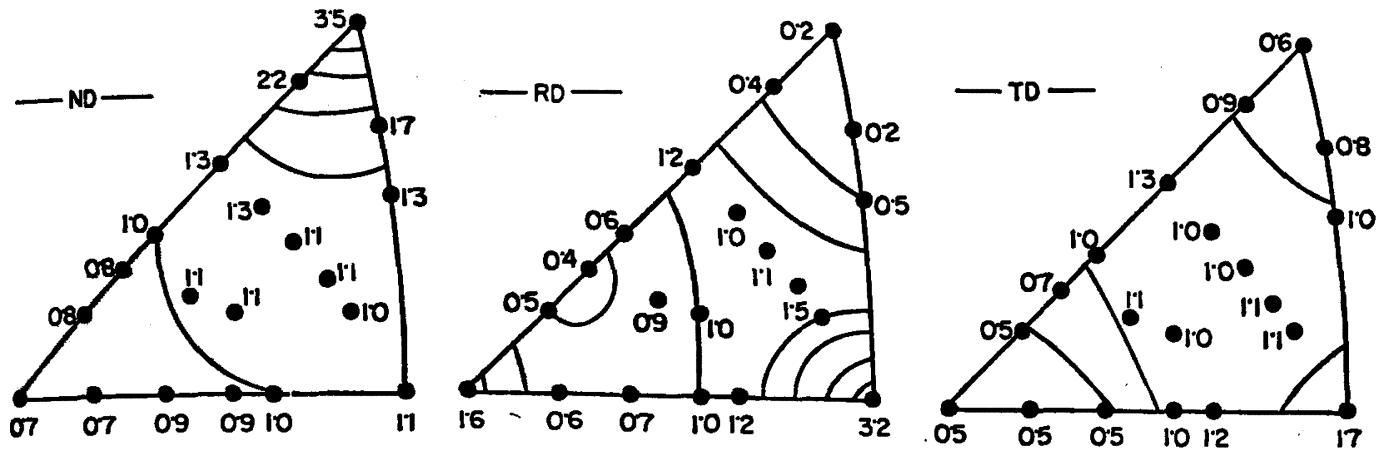

Fig. 28. Inverse pole figures of the same specimen shown in Fig. 27.

Table 4. $D$ and $r$ values as observed from tension tests and predicted from $\mathrm{X}$-ray pole figures.*

\begin{tabular}{|c|c|c|c|c|c|c|c|c|}
\hline \multirow{3}{*}{ Sample } & \multirow{3}{*}{ Orientation } & \multirow{3}{*}{$\begin{array}{r}\text { Testing } \\
\text { direction }\end{array}$} & \multicolumn{3}{|c|}{$D$ Values } & \multicolumn{3}{|c|}{ r Ratios* } \\
\hline & & & \multirow{2}{*}{$\begin{array}{l}\text { Tension } \\
\text { test } \\
\text { method }\end{array}$} & \multicolumn{2}{|c|}{ Pole figure method } & \multirow{2}{*}{$\begin{array}{l}\text { Tension } \\
\text { test } \\
\text { method }\end{array}$} & \multicolumn{2}{|c|}{ Pole figure method } \\
\hline & & & & $\begin{array}{l}\text { Maximum } \\
\text { intensity }\end{array}$ & Summation & & $\begin{array}{l}\text { Maximum } \\
\text { intensity }\end{array}$ & Summation \\
\hline $31 \mathrm{~K}$ & $(111)[\overline{110}]$ & $\begin{array}{l}\text { Odeg. } \\
45 \% \\
90 \%\end{array}$ & $\begin{array}{l}0.57 \\
0.27 \\
0.73\end{array}$ & $\begin{array}{l}0.50 \\
0 \cdot 24 \\
0.68\end{array}$ & $\begin{array}{l}0.20 \\
0 \cdot 19 \\
0.54\end{array}$ & $\begin{array}{l}1 \cdot 79 \\
1 \cdot 31 \\
2 \cdot 14\end{array}$ & $\begin{array}{l}1 \cdot 67 \\
1 \cdot 27 \\
2 \cdot 03\end{array}$ & $\begin{array}{l}1 \cdot 22 \\
1 \cdot 21 \\
1 \cdot 74\end{array}$ \\
\hline $95-16$ & $(411)[14 \overline{8}]$ & $\begin{array}{l}\text { Odeg. } \\
45 " \\
90 "\end{array}$ & $\begin{array}{l}-0.80 \\
-0.48 \\
-0.42\end{array}$ & $\begin{array}{l}-1 \cdot 15 \\
-0 \cdot 20 \\
-0 \cdot 53\end{array}$ & $\begin{array}{l}-0.57 \\
-0.27 \\
-0.55\end{array}$ & $\begin{array}{l}0.43 \\
0.61 \\
0.65\end{array}$ & $\begin{array}{l}0.27 \\
0.82 \\
0.58\end{array}$ & $\begin{array}{l}0.56 \\
0.76 \\
0.57\end{array}$ \\
\hline $99-16$ & $(100)[012]$ & $\begin{array}{l}\text { Odeg. } \\
45 " \\
90 "\end{array}$ & $\begin{array}{l}-1 \cdot 25 \\
-0 \cdot 47 \\
-1 \cdot 13\end{array}$ & $\begin{array}{l}-0.96 \\
-0.37 \\
-1 \cdot 10\end{array}$ & $\begin{array}{l}-0.90 \\
-0.38 \\
-1.00\end{array}$ & $\begin{array}{l}0.23 \\
0.62 \\
0 \cdot 28\end{array}$ & $\begin{array}{l}0.35 \\
0.69 \\
0.29\end{array}$ & $\begin{array}{l}0.38 \\
0.68 \\
0.33\end{array}$ \\
\hline $99-20$ & $\begin{array}{l}(100)[011] \\
(111)[112]\end{array}$ & $\begin{array}{l}\text { Odeg. } \\
45 " \\
90 "\end{array}$ & $\begin{array}{r}-0.21 \\
+0.09 \\
-0.23\end{array}$ & $\begin{array}{l}-0.02 \\
-0.05 \\
-0.34\end{array}$ & $\begin{array}{l}-0.65 \\
-0.10 \\
-0.42\end{array}$ & $\begin{array}{l}0.81 \\
1 \cdot 09 \\
0.79\end{array}$ & $\begin{array}{l}0: 98 \\
0.95 \\
0 \cdot 71\end{array}$ & $\begin{array}{l}0.51 \\
0.90 \\
0.65\end{array}$ \\
\hline
\end{tabular}

* $D$ values converted to $r$

* After Elias Heyer and SMrti1)

を求めることがてきる。

(b) 求和法

射断応力最大の位置, $\mathrm{S}_{\mathrm{MAX}}$, から $\pm 10^{\circ}$ の領域を考 え,これを $5^{\circ}$ 間隔の子午線で36箇の領域に分割する. それそれの領域の平均の $D$ 値次求めておき，次いでこの 骮老 (111) 極点困に重ねてこれらの領域に含まれる極の 密度を求める. Fig. 34 は TD 方向のD值を求める場 合を示したるので, $\mathrm{S}_{\mathrm{MAX}} \pm 10^{\circ}$ の D 值に極大値法の場 合と同様にそれぞれの軸密度を考虑して $36 \times 2$ の領域の Dの值の平均を求めるのである. Table 4 はストリップ 压延したキルド鋼およびリムド銅のr值を引張試釦で求 め,てれと極点図から推定した值とを比较して示したも のである.この值は（4）式に基ついているところに問 顆があるが，定性的には一致しており，極点因を直接利 用し複雑な計算によらすとに 值を求められる,きわめて ユニークな方法と言える。

\section{2 点图の傮先方位成分から計刑で求める方法}

集合組織を持つ多結晶体のr值を求める方法は, 結晶 粓界の影響を無視しても，瑐接する粒の拘束の影腊があ り単結晶の場合ほど容易ではない。岡本, 白岩, 福田 24 は単結晶に関する計算結果を多結晶体の変形の場合に適 用できるように，(a) 分解剪断応力の大きい 2 つの之 り系によつて変形すると考元，(b) $\tau(110) \cong \tau(112) \cong \tau \tau_{(128)}$ と仮定して, 以下の 8 主要方位の単結晶の基準軸から $0^{\circ}, 45^{\circ}, 90^{\circ}$ 方向の昰および $r$ 值を求めた. 計算を行 なつた方位は (100) [011]， (112) [1110]，(111) [112]， (100)<[011]から $15^{\circ}$ 右まわり $>,(100)<[011]$ から $15^{\circ}$ 左まわり>, (110) [001] で上述の極低炭素鋼板の集合 組織における主要なるのを選んである.

その後岡本らはさらに4個のモデルについて, 引張方 向も基準方向か $50^{\circ} \sim 180^{\circ}$ の間の方向についてr值を計 算した25). そのモデルは,

（a） 分解茄断応力最大の単一系による亡り変形, $\left(R^{1}\right)$. 

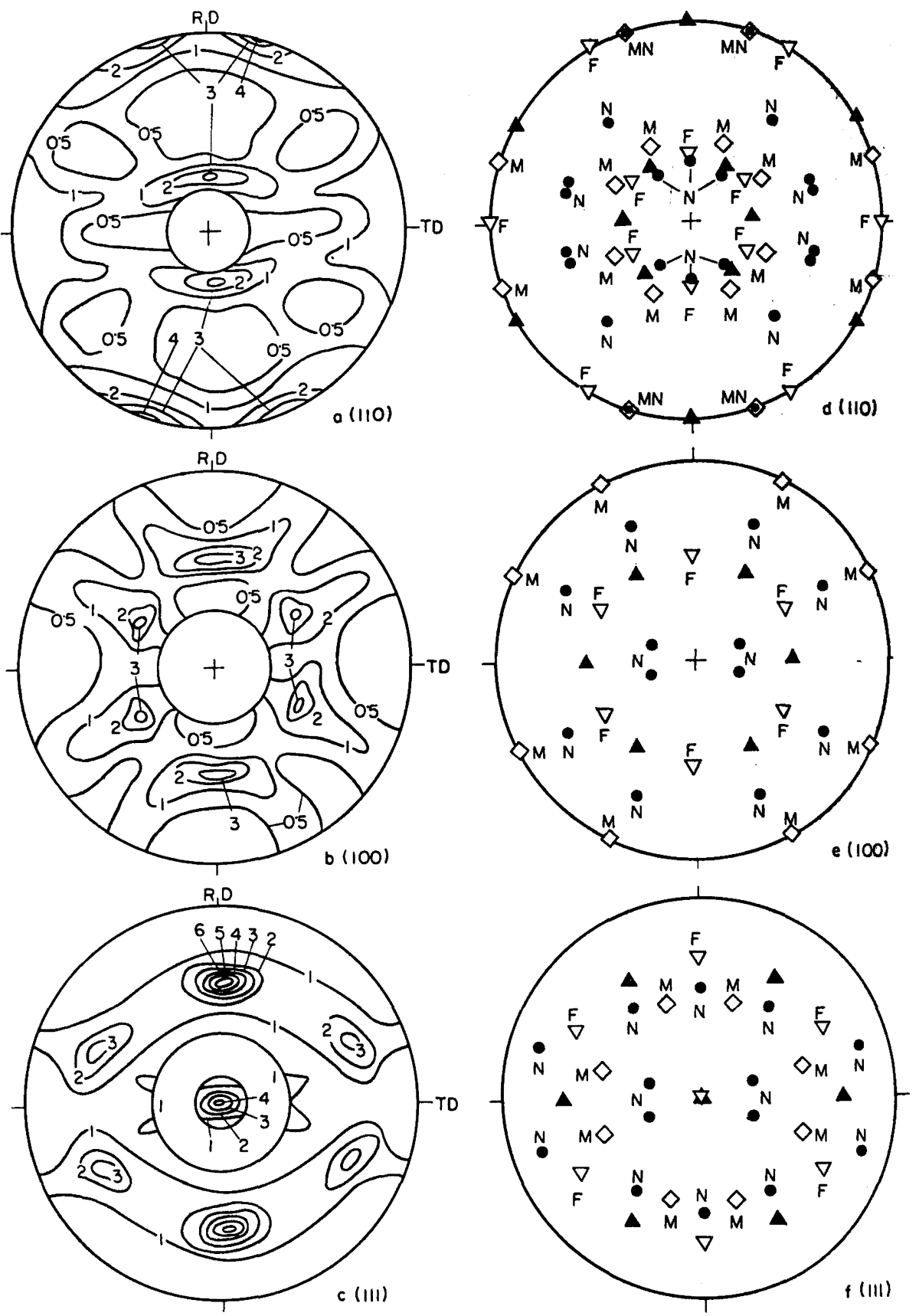

Fig. 29. (110), (100) and (111) pole figures of low carbon steel sheet, cold-rolled $90 \%$ and annealed at $800^{\circ} \mathrm{C}$ for $4 \mathrm{hr}$. 

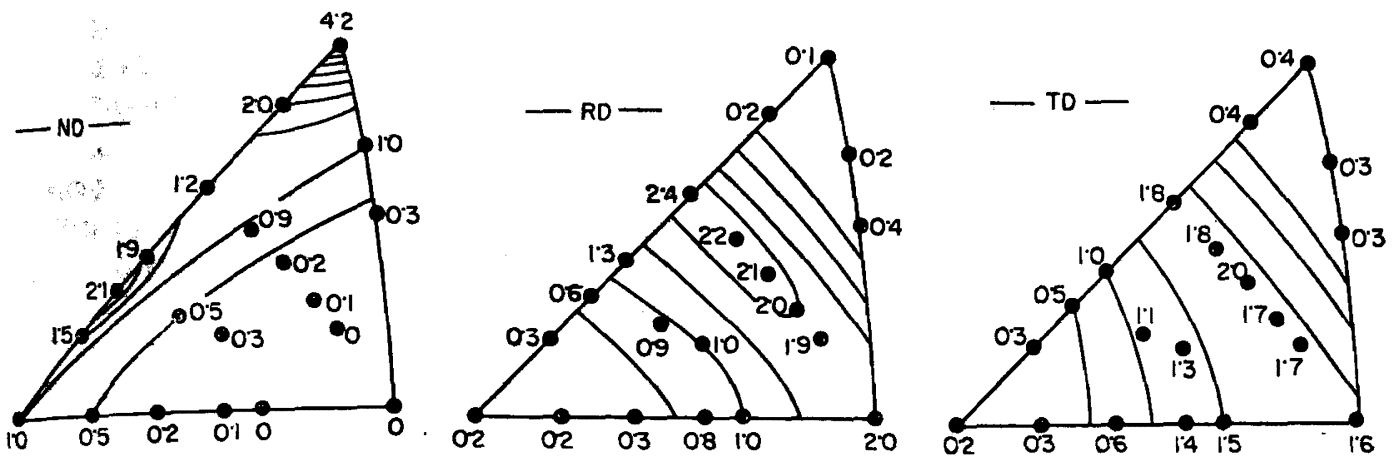

Fig. 30. Inverse pole figures of the same specimen shown in Fig. 29.
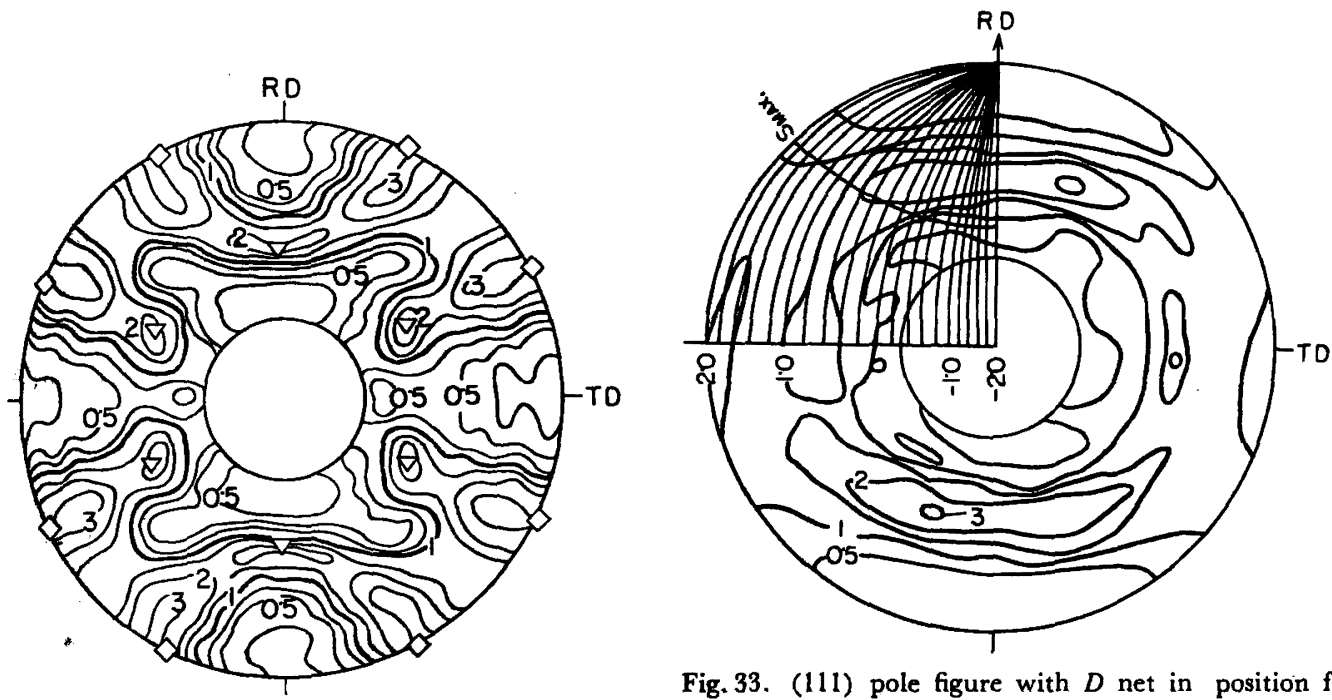

Fig. 31. (100) pole figure of rimmed steel sheet, cold-rolled $97.5 \%$ and annealed at $688^{\circ} \mathrm{C}$. (HEYer et al.21)

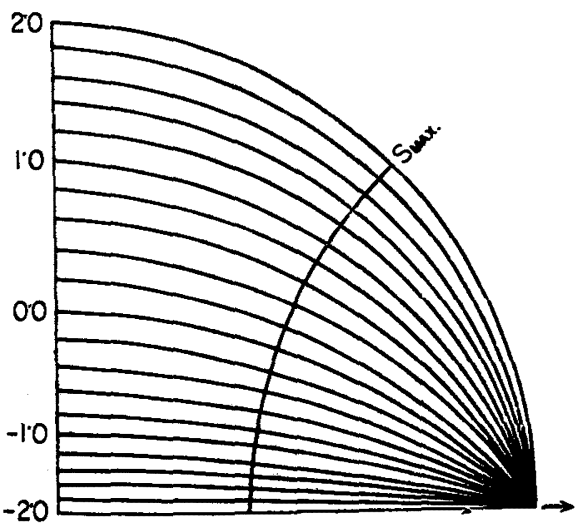

Fig. 32. Iso- $D$ net with arrow representing direction of straining. (Elus et al. ${ }^{11)}$ )
Fig. 33. (111) pole figure with $D$ net in position for longitudinal direction. (Elias et al.11)

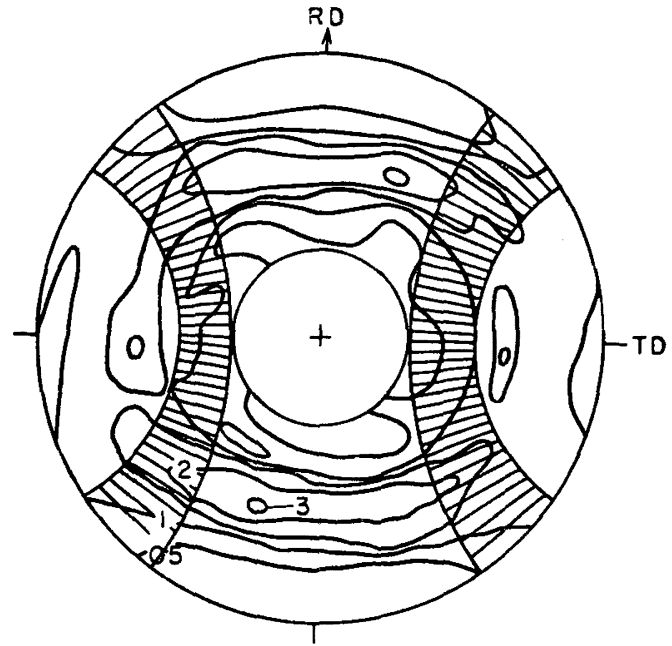

Fig. 34. (111) pole figure with incremental overlap \pm 10 deg. to the small circle representing maximum shear stress. (Elias et al.11)) 
（b）分解剪断応力最大の采と，その次に大きい系と の 2 つ过り系による変形， $\left(R^{2}\right)$

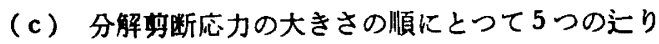
系による変形, $\left(R^{5}\right)$

(d) 上記のモデルによつて求めた $r$ 值の平均値, $\left.\left(<R^{5}\right\rangle\right)$.

これらのモデルの中で $R^{2}$ ，および $R^{5}$ によつて主要な 4 方位 (100) [011]，（111)[112]，（110) [001] および (112) [110] Kついて, 引張方向による r值の変化する 例を Fig. 35 に示した.なお, 岡本らは数個の優先方 位が重畳したときの，值の変化を加算して求められるよ $j k$, 試料の愊, 厚さ, 長さ方向の昰 $\varepsilon_{w}, \varepsilon_{t}, \varepsilon_{l}$ をす べて計算していて，罒には $\bar{\varphi}=-\varepsilon_{w} / \varepsilon_{l}$ なるパラメータ を採用している.

\section{3 反枟颃点図から求める方法}

（i） 変形に関するモデルの設定

著者らは多結晶体の, 值を計算によつて求めるに当た つて, ELIAS らの提唱した $D$ 值に似た異方性パラメータ を設定し，集合組織を定量的に示すためには反転極点困 から得られる軸密度分布を用いて，集合組織を持つ薄銅 板の值を計算によつて求めようと試みた ${ }^{26) 27) . ~}$

計算に当たつて次のような仮定をおいた。

(a) 各結晶粒の引張方向の伸び $\varepsilon_{l}$ はすべて等しい. また幅, 厚さ方向の麥 $\varepsilon_{w}, \varepsilon_{t}$ は等しいとは限らないが 各結晶粒についての平均値 $\varepsilon_{w}, \bar{\varepsilon}_{t}$ は試駼片の巨視的歪 に等しい.すなわち,

$$
\bar{\varepsilon}_{l}=\varepsilon_{l}=E_{l}, \quad \bar{\varepsilon}_{t}=E_{t}, \quad \bar{\varepsilon}_{: v}=E_{w}
$$

ここに $E_{l}, E_{t}, E_{\text {tv }}$ はそれぞれ試験片の引張方向, 厚 さおよび幅方向の巨視的昰を表わす。

（b）引張による集合組織の变化は無視する.すなわ ち結晶の回転は考慮に入れない。
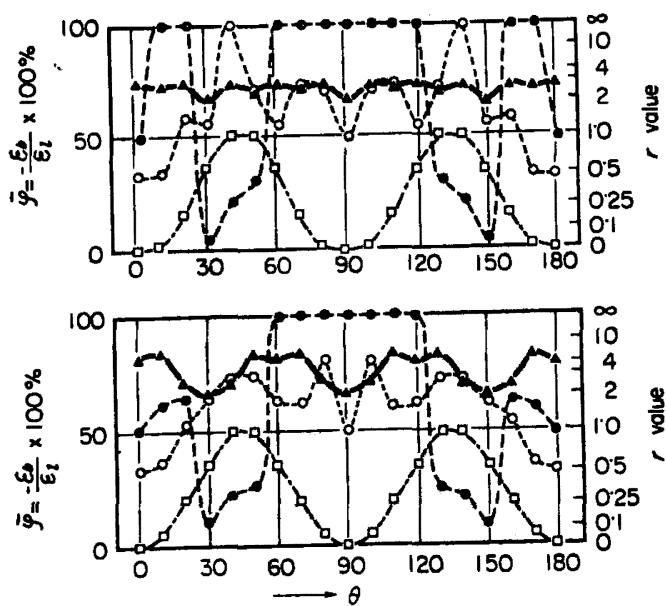

Fig. 35. Plastic strain ratio $r$ and ratio between width and longitudinal strains $\bar{\varphi}$ for the several orientations. (Окамото et al.,25)) （c）試験片中の1つの粒に注目して，その䊉がどの シり采でどれだけシるかという問題は，隣接する䊉から の影很で非常に複雑となるが，同一方位の粒の平均的挙 動はつぎのモデルにしたがうるのと仮定する.1つの結 晶に外力が加えられたとき, 実際に迄りがおこるのはと の汇り系での schmid 因子が 0.25 以上のものに限り, かつその系の汇り量は schmid 因子に比例するむのとす る. すなわち，1つの方位についてそのうり系の番号を 添字 $n$ で表わし，その采での迄り量を $d \gamma_{n}$, その系の schmid 因子を $M_{X n}=\cos \lambda_{n} \cos \varphi_{n}$ とすると，この仮定 は次式で表わされる.

$$
\left.\begin{array}{ll}
d \gamma_{n}=K\left(M_{X_{n}}-0.25\right), & M_{X_{n}}>0.25 \\
d \gamma_{n}=0, & M_{X_{n}} \leqq 0.25
\end{array}\right\}
$$

(d) 荺断昰 $\gamma_{Y X}, \gamma_{Z X}, \gamma_{Y Z}$ は単一の方位ではゼ口 とはならないが，各方位にわたつて和をとれば，板状試 験片の方位についての対称性のためにゼ口となるので考 虑しない。

次に下記のような異方性パラメータ $D_{0}$ を設定する. 上述の長さ, 幅, 厚さ方向の巨視的昰, $E_{l}, E_{w}, E_{t}$ に ついて

$$
\begin{aligned}
& E_{t}=-E_{l}\left(1-D_{0}\right) / 2 \\
& E_{w}=-E_{l}\left(1+D_{0}\right) / 2
\end{aligned}
$$

とすると, この $D_{0}$ とて値との間には

$$
\left.\begin{array}{c}
D_{0}=\frac{E_{t}-E_{w}}{E_{l}}=\frac{E_{w} / E_{t}-1}{E_{w} / E_{t}+1}=\frac{r-1}{r+1} \\
r=\frac{1+D_{0}}{1-D_{0}}
\end{array}\right\}
$$

なる関係がある.したがつて $D_{0}$ は 1 とー1 との間て変

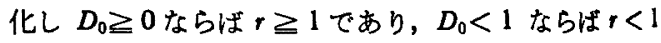
となる.

さらに任意の方位の結晶粒についても同様にパラメー 夕 $D_{0}(\alpha, \beta: \theta)$ を次のように定義する.

$$
D_{0}(\alpha, \beta: \theta)=\frac{\varepsilon_{t}-\varepsilon_{w}}{\varepsilon_{l}}
$$

ただし， $\alpha, \beta, \theta$ は方位を定める变数であり，Fig. 36 に示すように $\alpha, \beta$ は板面法線を定める变数, $\theta$ は板面

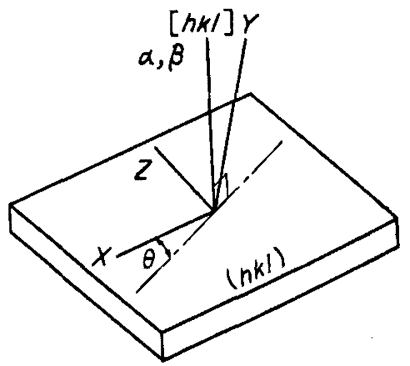

Fig. 36. Angle between the coordinate determing specimen shape and standard direction SD on the crystallographic plane $(h k l)$. 
内である基準線からの角度を示す変数である。

1 蝴の $\alpha, \beta, \theta$ に対して $D_{0}(\alpha, \beta: \theta)$ を考えよう. 翻の汇り系上で $d \gamma_{n}$ だけ迄り，その系における $X$, Y, Z 咀についての schmid 因子が $M_{X_{n}}, M_{Y_{n}}, M_{Z_{n}}$ であるとする. 各方向の星は，

$$
\left.\begin{array}{l}
\varepsilon_{X}=\Sigma M_{X n} d \gamma_{n} \\
\varepsilon_{Y}=\Sigma M_{Y n} d \gamma_{n} \\
\varepsilon_{Z}=\Sigma M_{Z_{n}} d \gamma_{n}
\end{array}\right\}
$$

となる. 和は式り系 48 個のうち可能なものすべてにつ いてとる.（c）の仮定から

$$
\begin{aligned}
& D_{0}(\alpha, \beta: \theta)=\frac{\varepsilon Y-\varepsilon Z}{\varepsilon_{X}} \\
& =\frac{\sum_{n}^{\prime}\left(D_{2 n} E_{2 n}-D_{3 n} E_{3 n}\right)\left(D_{1 n} E_{1 n}-0.25\right)}{\sum_{n}^{\prime} D_{1 n} E_{1 n}\left(D_{1 n} E_{1 n}-0.25\right)} \ldots(13) *
\end{aligned}
$$

ただし $D_{1 n} E_{1 n}$ はつねに正なる向きにとり， $\Sigma^{\prime}$ は $D_{1 n}$ $E_{1 n}>0.25$ のみの和を求めるものとする.

試駼片が集合組織を持つときの $D_{0}$ 值は次のように表 わされる. まず集合組織は分布函数 $P(\alpha, \beta: \theta)$ で表わ されるとする. Fig. 37 に示すように, 基準方向から角 度 $\rho$ なる方向に引張つたときの $D_{0}$ 値は仮定 (a)により

$$
D_{0}(\rho)=\frac{E_{Y}-E_{Z}}{E_{X}}=\left(\overline{\frac{\varepsilon_{Y}-\varepsilon_{Z}}{\varepsilon_{X}}}\right)
$$

一方,

$$
\begin{array}{r}
D_{0}(\rho)=\iiint D_{0}(\alpha, \beta: \theta) P(\alpha, \beta: \theta-\rho) \\
d \alpha d \beta d \theta
\end{array}
$$

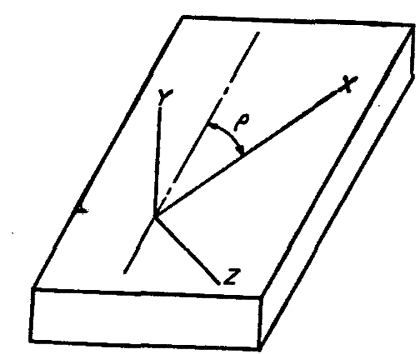

Fig. 37. Angle between the coordinate of specimen shape and tensile direction TD.

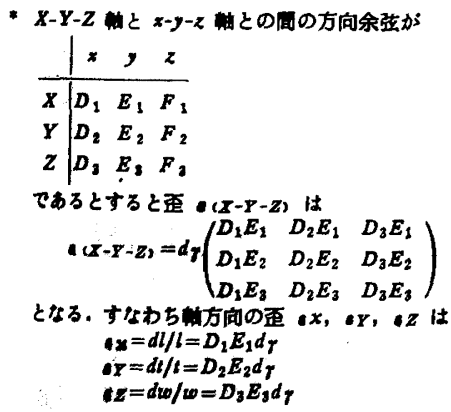

である. $D_{0}(\rho)$ の についての平均値 $\bar{D}_{0}$ を考えると

$$
\left.\begin{array}{l}
\bar{D}_{0}=\frac{\int D_{0}(\rho) d \rho}{\int d \rho}=\frac{1}{\int d \rho} \iiint \\
D_{0}(\alpha, \beta: \theta)\left[\int P(\alpha, \beta: \theta-\rho) d \rho\right] d \alpha d \beta d \theta \\
\int P(\alpha, \beta: \theta) d \theta=\bar{P}(\alpha, \beta) \\
\frac{\int D_{0}(\alpha, \beta: \theta) d \theta}{\int d \theta}=\bar{D}_{0}(\alpha, \beta)
\end{array}\right\} \ldots \ldots . .
$$

いまとおくと,

$$
\bar{D}_{0}=\iint \bar{D}_{0}(\alpha, \beta) \bar{P}(\alpha, \beta) d \alpha d \beta
$$

となる。

したがつて， $\alpha, \beta$ で示される結晶面の任意の方向に ついての個々の $D_{0}$ 值はこの計算からは求められず, $\theta$ の. $0^{\circ} \sim 360^{\circ}$ の方向の平均值が与えられる. ここで $\bar{P}$

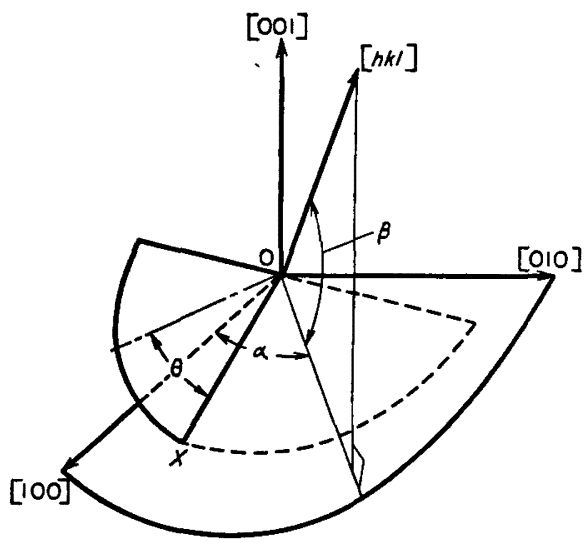

Fig. 38. Angle between the crystallographic plane $(h k l)$ and the three $\langle 100\rangle$ axes taken as a new coordinate.

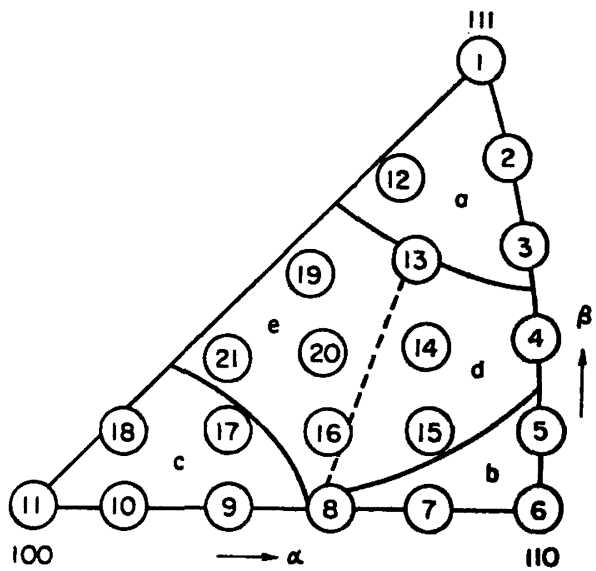

Fig. 39. The position of ( $h k l)$ planes for various $(\alpha, \beta)$ values.

$\alpha=0,9,18, \cdots \cdots \cdots, 45^{\circ}$

$\beta=0,7,14, \cdots \cdots \cdots, 35^{\circ}$ 


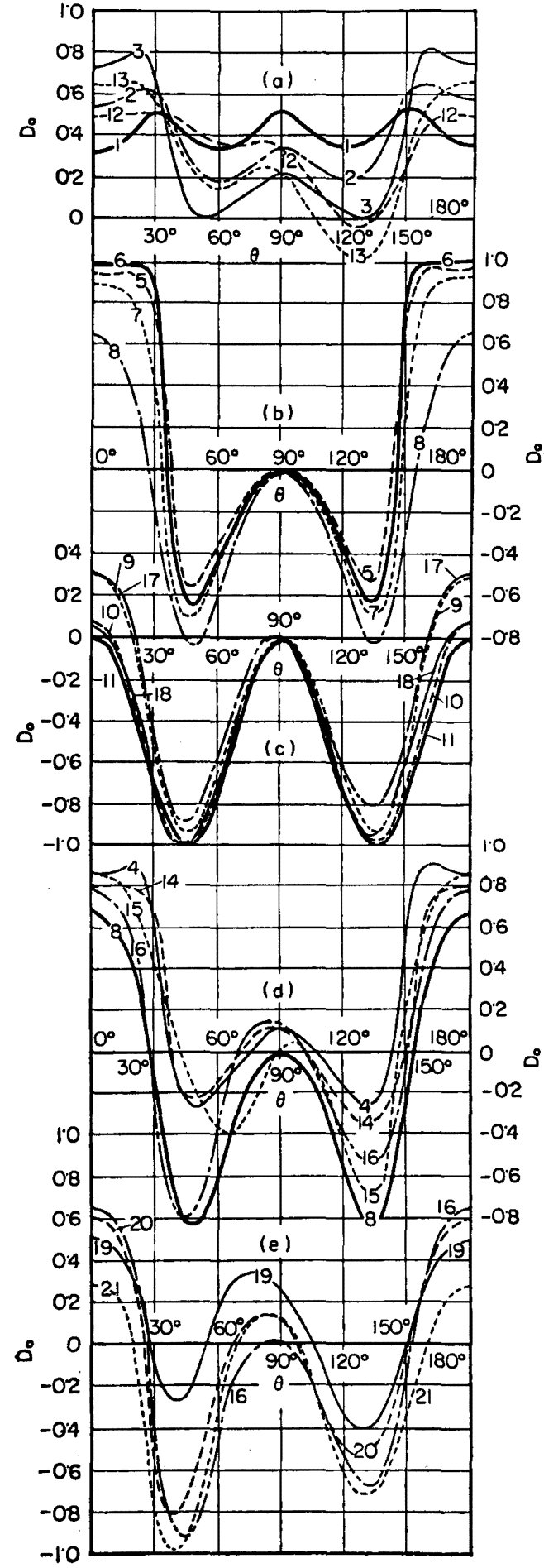

Fig. 40. Calculated $D_{0}(\alpha, \beta: \theta)$ values in bcc iron. $(\alpha, \beta)$ は $\alpha, \beta$ なる力位の結晶が板面に平行になる雄 率, すなわち板面に垂直な軸の反転極点図上の軸密度に ほかならないそれゆえ， $\bar{D}_{0}$ は $\bar{D}_{0}(\alpha, \beta)$ ND 反 転極点図の $\alpha, \beta$ 方位の軸密度の重みをつけて程分した 值である. 現在のところ実験的に完全な反転極点困を求 めること注困難であるが，短波長の特性X線を使用する と 10 個以上の主要な結晶面についての密度を測定でき るので，(18)式はつぎのように近似することができる.

$$
D_{0}=\Sigma \bar{D}_{0 h k l} \cdot \bar{P}_{h k l}
$$

(ii) $\alpha$ 鉄における $D_{0}$ 值の計算

上記岡本ら ${ }^{24) 25)}$ と同様に $\alpha$ 鉄において $\tau_{(110) \cong \tau_{(112)} \cong}$ て(128)と仮定すると 48 個の迄り系が存在する.これらの 系が仮定（c）にしたがつて活動し过りが進行すると考 えて $D_{0}$ 值を求めてみよう. まず Fig. 38 の $\alpha, \beta$ で表 わされる方位の結晶につき, その結晶面内の基準方向, $O X$ からの角度 $\theta$ なる方向に引張つたときの $D_{0}(\alpha, \beta: \theta)$ を小型電子計算機を用いて計算を行なつた， $\alpha, \beta, \theta$ の数値は下記のようにとつた.

$$
\begin{aligned}
& \alpha=0^{\circ}, 9^{\circ}, 18^{\circ}, \cdots \cdots \cdots \cdots, 45^{\circ} \\
& \beta=0^{\circ}, 7^{\circ}, 14^{\circ}, \cdots \cdots \cdots \cdots, 35^{\circ} \\
& \theta=0^{\circ} \sim 180^{\circ}
\end{aligned}
$$

方位 $(\alpha, \beta)$ はステレオ三角形内の位置を示すとFig. 39 のような21 個になる.

計算の結果は Fig. 40 に示すとおりで， $D_{0}-\theta$ 曲線は 4 グループに大別できる.

（1）（111）およびこれに近い方位のもので Fig. 40 (a)に示すように $D_{0}$ 值はつねに正であり， $\theta$ が約 $30^{\circ}$, $90^{\circ}, 150^{\circ}$ に極大值を持つ.

（2）（110）およびこれに近い方位のもので， $\theta$ かi0 および $180^{\circ}$ に極大値, $90^{\circ}$ に $D_{0}=0$ の副極大を持ち, $45^{\circ}$ および $135^{\circ}$ に極小値を持つ. (Fig. 40(b))

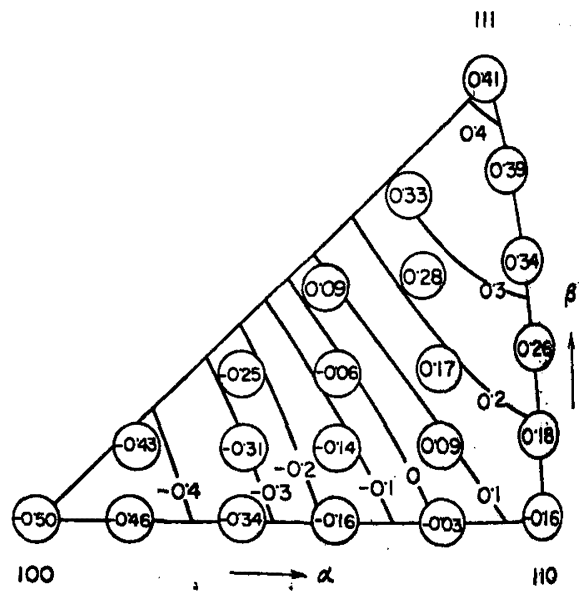

Fig. 41. Distribution of $\bar{D}(\alpha, \beta)$ value shown in a unit stereographic triangle. 
Table 5. Averaged plastic anisotroy parameter $\bar{D}_{0 k k l}$ for bcc iron.

\begin{tabular}{|c|c|c|c|c|c|c|c|c|c|c|c|}
\hline$h k l$ & 100 & 110 & 111 & 210 & 211 & 221 & 310 & 321 & 332 & 411 & 521 \\
\hline $\bar{D}_{0}$ & -0.50 & 0.16 & 0.41 & $-0 \cdot 17$ & $0 \cdot 13$ & 0.31 & -0.34 & $0 \cdot 16$ & $0 \cdot 37$ & -0.27 & -0.21 \\
\hline
\end{tabular}

Table 6. Experimental results $\bar{P}(\alpha, \beta)$ observed, calculated $\bar{D}_{0}$-values and observed $\bar{D}_{0}$-values.

\begin{tabular}{rl|r|r|r|r|r|r|r|r|r|r|r|r|r|r}
\hline \\
\hline
\end{tabular}

Table 7. Calculated $D_{0}$ value for the specimen shown in Fig. 42.

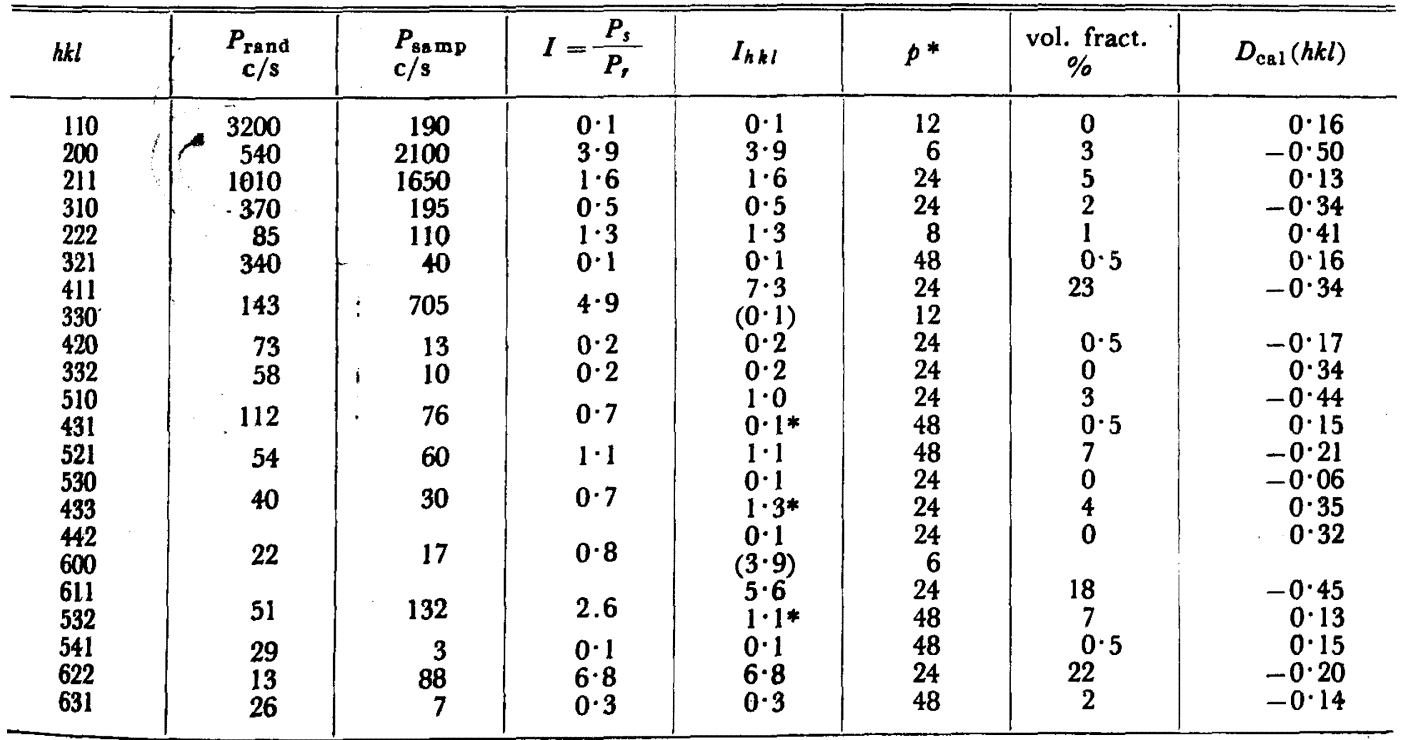

p: multiplicity factor 

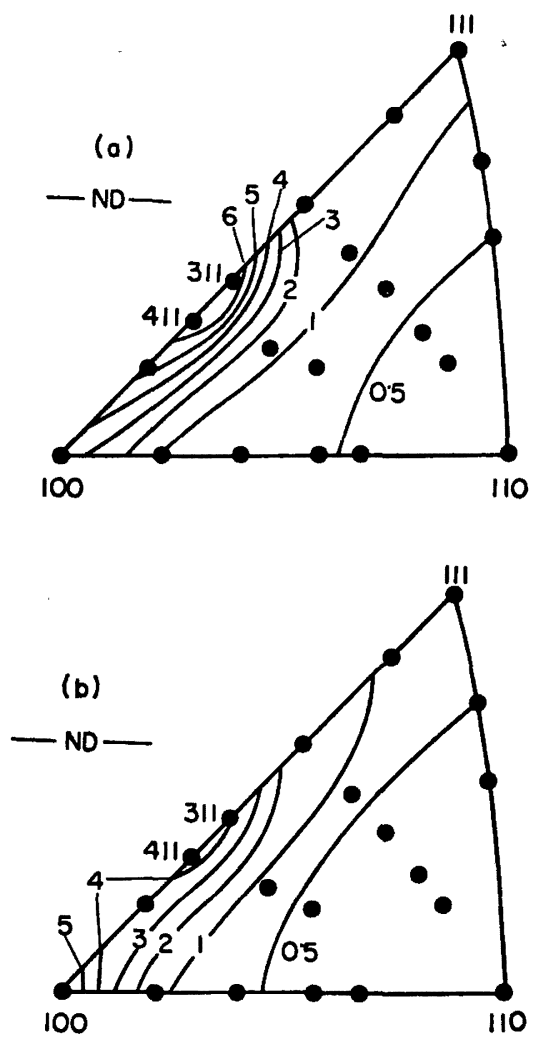

Fig. 42. Change in texture during tensile deformation. Inverse pole figure of low carbon rimmed steel sheet, cold rolled $97 \%$ and annealed at $850^{\circ} \mathrm{C}$ for $4 \mathrm{hr}$. (a) Before elongation, (b) After 15\% elongation along rolling direction.

(3) (100) およびその近くの方位のあので， $\theta$ の 全角にわたつて $D_{0}$ が負であり， $0^{\circ}, 90^{\circ}, 180^{\circ}$ に極大 値を, $45^{\circ}$ および $135^{\circ}$ に極小値を持つ. (Fig. 40(c))

(4) 以上 3 グループの中間の方位のもので， $D_{0}$ は $0^{\circ}, 90^{\circ}, 180^{\circ}$ 付近に極大值を, $45^{\circ}, 135^{\circ}$ 付近深小 值を持つ. (Fig. 40(d), (e))

この四中のそれぞれの方位の曲線の $\theta$ についての $D_{0}$ 值の平均を求めると Fig. 41 に示すよらになる. また これらから内捜によつて $\bar{D}_{0 h k l}$ を求めると Table 5 に 示す数值が得られる.

実際の鋼板について実測值と反転極点図から求めた值 とを比较してみよう. 測定に供した $\mathrm{Al}$ キルド鋼の $D_{0}$ $\theta$ の形は $45^{\circ}$ 方向の $D_{D}$ が最低値をとり， $0^{\circ}$ 側およ び $90^{\circ}$ 側の $D_{L}, D_{T}$ はいずれも增加し，かつ $D_{L}<D_{T}$ となつている. この $D_{0}$ の形は Fig. 40 における 6〜 10の方位の $D_{0}-\theta$ 曲線の $\theta=90^{\circ}$ から $180^{\circ}$ までの変化 の傾向に似ており, $\theta=90^{\circ}$ は (001), $\theta=180^{\circ}$ は(110) に相当する ${ }^{26)}$. さらにこの四の(b)〜 (e )のグループの
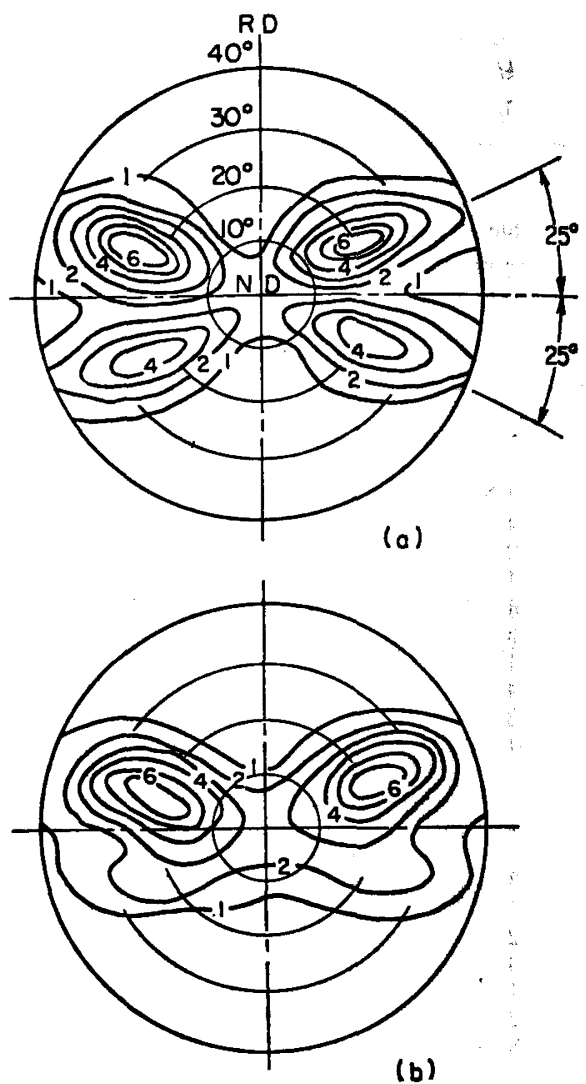

(b)

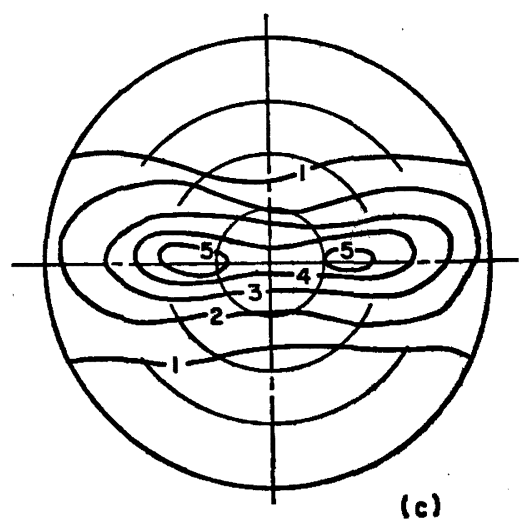

Fig. 43. Change in texture during tensile deformation. (100) pole figure of the same specimen shown in Fig. 42. (a) Before elongation, (b) After 20\% elongation along rolling direction, (c) After $38 \%$ elongation.

曲線の $\theta=90$ 〜 $180^{\circ}$ はほほこのような傾向を示ナここ の型の $D_{0}$ の分布を持つものの $\bar{D}_{0}$.を求めると Table 6 に示すように大変よい一致が認められる. 


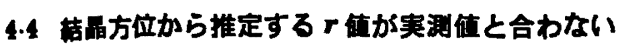 场合}

(i) 引張変形中の結晶回転

上述の結晶方位からｒ值を推定しようとする多くの試 みにおいては，変形中の結晶回転はきわめて小さいか, あ石いは $\varepsilon_{w} / \varepsilon_{t}$ には大きな变化を与えないといら仮定 に基ゔいて計算をすすめてきた．幸いなことに，一般の 命延嫃鈍によつて得られる鋼板においては，この仮定が ほ活通用し推定値と実測值の間にはかなりよい一致が認 められた.

本節においては，さらに考えをすすめて引張変形中の

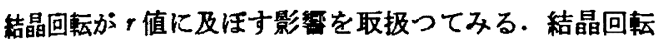
の $D_{0}$ 值への寄与は集合組織の分布状態を変えることを 通してなされると考えられる.したがつて (15) 式ある W性 (18) 式の $P(\alpha, \beta: \theta-\rho), \bar{P}(\alpha, \beta)$ は実虫引張方 向の歪 $E_{X}$ の関数と見なければならない，それゆえ上述 の計算怯 $E_{X}=0$ のときの $\bar{P}(\alpha, \beta)$ を用い，変形初期 の $\bar{D}_{0}$ 値を推測していることになる. いま任意の引張歪 $E_{X}$ のときの $D_{0}(\rho)$ 値は

$$
\begin{aligned}
& D_{E X}(\rho)=\frac{d E_{Y}-d E_{Z}}{d E_{X}} \\
= & \iiint D_{0}(\alpha, \beta: \theta) P_{E X}(\alpha, \beta: \theta-\rho) d \alpha d \beta d \theta
\end{aligned}
$$

で表わされる. ここで $d E_{Y}, d E_{Z}$ は引張方向の麥が $E_{X}$ 加 $E_{X}+d E_{X}$ にふえる際の厚さおよび愊方向巫の增分 である.

したがつて最終泰 $E_{X}^{\circ}$ までの平均的 $D_{0}$ 值, $D_{\mathrm{tot}}(\rho)$ 住

$$
D_{\text {tot }}(\rho)=\frac{E_{X}^{\circ}-E_{Z}^{\circ}}{E_{X}^{\circ}}=\frac{\int_{0}^{E_{X}^{\circ} D_{E X}(\rho) d E_{X}}}{E_{X}^{\circ}}
$$

となる. 初期の分布函数 $P_{0}(\alpha, \beta: \theta)$ を与え, $P_{E X}(\alpha$, $\beta: \theta)$ を求める問題を理論的に解くことは不可能である が, 引張変形の各段階で $T_{E X}(\alpha, \beta)$ を実験的に求める ことは可能であり，(21)式によつて平均的な $\bar{D}_{\text {tot }}$ を求 められる。

\section{(ii) 引張変形中の結晶回転の 1 例}

低炭素りムド鋼を高い压延率で冷延し，高温度で焼鈍

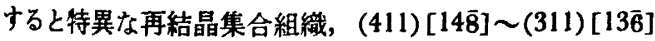
加得られる. Fig. 42 (a) は $97 \%$ 冷延後 $850^{\circ} \mathrm{C} て ゙ 4$ $\mathrm{hr}$ 焼釷したものの ND 反転極点四である.この試料の 引張試駼隹より求めた $r$ 値は次のとおりである.

$r_{L}=0.24, r_{D}=0.61, r_{T}=0.29 ; \quad \bar{r}=0.43$

一方初期方位から推定される值は Table 7 に示した $D_{(h k l)}$ から次のよ5になる。

$$
\bar{D}_{\mathrm{eal}}=-0.22 ; \bar{r}_{\mathrm{eal}}=0.64
$$

この峝者の差恃上述の Table 6 の結果から考えると きわめて大きいもので，，值を測定するために引張変形
を与えた際の結晶回転によるものと考えられる．この考 えを確かめるために，引張変形途中の集合組織の変化を 調べてみた. Fig. 42 (b) は压延方向へ $15 \%$ 引張つ た後の $N D$ 反転極点図である.（a )にくらべて 411, 311 が減少し 100 方位が增加しているのがよくわかる。 引張変形中の結晶回転は極点図を見ると一層明らかで, Fig. 43 に示すようになる.この図は反射法により中心 から $40^{\circ}$ 以内の極点四を求めたものであるが，初方位 は (100) 極が中心から約 $20^{\circ}$, 水平方向から約 $25^{\circ} の$ 点に集䅡している． $R D$ 方向への变形が進むにしたがつ てこの集稳点は水平線上に向かい，かつ中心点に向かつ て移動することがわかる.この移動は次に示す結晶回転 に対応する.

$$
\begin{aligned}
& N D:(311) \rightarrow(411) \rightarrow(611) \rightarrow(100) \\
& R D:[13 \overline{6}] \approx[01 \overline{1}] \pm 25^{\circ} \rightarrow[14 \overline{8}] \rightarrow[011]
\end{aligned}
$$

試料面法線のこのような $(100)$ 方位への回転は $\bar{r}$ 值が 位い方位が増加する回転であるから，上述のて実測值か 初期方位から推定した値よりも低いことは定性的に説明 できる.なおこのような結晶回転は汇り系の幾何学的考 察によつて容易に説明できる.

\section{む す $ひ$}

以上，本稿では結晶塑性学的立場からプレス成形性の 中でも特に哚絞り性と集合組織との関係について述べ た. 薄鋼板の成形性に関する一般的, あるいは材料力学 的立場からの解説はほかに適当な報告が多いのでそれら を参照祀していただきたい。

なお，本稿の執箻に当たつて内容に関する討議あるい は資料の収集などでお世話になつた加藤弘君はじめ研究 室の諸君に心から御礼を申し上げる.

\section{文城}

1) 阿部: 鉄と銅，52（1966） 5 , p. 882

2) $W . T$. Lankford, $S . C$. SNYder and $T . A$. BAusher: Trans. AIME, 42 (1950), p. 1197

3) C. S. BARRETT: "Structure of Metals", (1943), p. 450. McGraw-Hill Book Co., Inc., New York

4 ) "Recording Torque Magnetometer", Mechanical Engineering, 71 (1949), p. 510

5) $R$. S. BUrns and R. H. HeYer: Sheet Metal Ind., 35 (1958), p. 261

6) R. L. Whiteley and D. E. Wise: Flat Rolled Products I, 16 (1962), p. 47

7) 伊臊, 神䗁: 铁と鋼, 52 (1966) 8, p. 1188

8 ) 長島, 関野, 加藤: 日本金属学会誌, 27 (1963), p. 481

9) $H$. Takechi, $H$. Kato and $S$. Nagashima: Trans. Met. Soc. AIME, 242 (1968), p. 56

10) $R$. W. Vieth and $R$. L. Whiteley: Colloquium of IDDRG, Inst. Sheet Metal Engineering, London, (1964)

11) $J . A$. Elias, $R$. H. Heyer and $J \cdot M$. Smith: 
Trans. AIME, 224 (1962), p. 679

12）長島：集合組織，(1966), 日本金属学会金属学新 書

13) F. Hässner u. H. Weik: Arch. Eisenh., 27 (1956), p. 153

14) J. Bennewitz: ibid., 33 (1962), p. 393

15) H. MölleR u. H. StäBlein: ibid., 29 (1958), p. 377

16) W. C. Leslie: Trans. AIME, 221 (1961), p. 752

17) $M$. Gensamer and $P$. $A$. Vukmanic: ibid., 125 (1937), p. 507

18) N. P. Goss: Trans. ASM, 29 (1941), p. 20

19) G. Kurdjumov u. G. SACHs: Z. Metallk., (1930), p. 592

20) $M$. Gensamer and $B$. Lustman: Trans. AIME, 125 (1937), p. 501

2I) R. H. Heyer, D. E. McCabe and J. A. Elias: Flat Rolled Products I, 16 (1962), p. 29

22) 五弓, 阿部, 上山: 日本金愿学会誌, 28(1964), p. 542

23) W. F. Hosford: Trans. AIME, 227 (1963), p. 272

24) 岡本, 白岩, 福田: 住友金属, 14 (1962), p.21!

25) $T$. Okamoto, $T$. Shiraiwa and $M$. Fukuda: Colloquium of International Deep Drawing Research Group, Institute of Sheet Metal Engineering, London, 1964

26）長島, 武智, 加藤：日本金属学会誌, 29(1965), p. 393

27）加藤, 武智, 長島: 塑性と加工, 7(1966) 1, p. 13

28）たとえば，中島，获間，長島：日本金属学会報， 6 (1967) 10, p. 699

鉄之鈵，鉄鋼技術の進歩特集号，51（1965）3， p. 504

福井, 吉田, 阿部: 日本金属学会誌, 1 (1962) 5, p. 359など 